\title{
Impact of Privatization on Health Sector in Kingdom of Saudi Arabia
}

\author{
Hanan Hamad Aljobailan \\ College of Business and Economics, Qassim University, Saudi Arabia
}

\begin{abstract}
Saudi Arabia has announced the launch of its health projects for privatization within the framework of the economic transformation adopted by the government. The objectives of the research are to examine the impact of privatization on the health sector in terms of government expenditure, beneficiary satisfaction, improve management, and improvement of the working environment of health practitioners. In this study, the descriptive quantitative approach was used, primary data collected by distribute questionnaire to 200 respondents. The data were analyzed by means of several statistical methods and data tests, which include: descriptive analysis, correlation analysis, factor analysis, and reliability and regression analysis using the SPSS program. This study concluded that privatization has a positive impact on dependent variables (government expenditure, beneficiary satisfaction, management improvement, and improvement of the working environment of health practitioners). Based on the results of the study, a set of recommendations were presented.
\end{abstract}

Keywords: Privatization, Health Sector, Kingdom of Saudi Arabia, Government Expenditure, Beneficiary Satisfaction, Management improvement, Working Environment of Health Practitioners.

DOI: $10.7176 / \mathrm{EJBM} / 12-36-10$

Publication date: December $31^{\text {st }} 2020$

\section{Introduction}

In 2017, with the launch of Vision 2030, the Kingdom of Saudi Arabia announced that it will privatize 18 ministries, including the Ministry of Health, to complete the work already begun in 2014. As the Ministry of Health began the privatization journey by outsourcing some of its health centres and giving it to outside contractors, also, to employ health practitioners had a share of privatization. And because of the increasing demand for health services and the large expenditure on them, which takes a large share of the government budget and also there are pressing demands to improve the service provide to patients and provide a good work environment for health professionals. The subject of privatization of the health sector has become the aim at providing satisfaction to all parties concerned.

Accordingly, the privatization of the health sector in Saudi Arabia is a worthy subject of research and study because Health Ministry is one of the most important ministries in the country and is the main health services provider, also because the studies are relatively few. Based on the above, this research highlights the privatization of Health Ministry's hospitals, and to the attention of its officials on the set of ideas relate to the privatization of hospitals.

\section{1-1 Background information:}

In recent years, privatization has become the focus of governments and public sector institutions throughout the world and has gain its share of interest in the Arab world recently. Saudi Arabia has announced the privatization of several institutions affiliated to ministries including the Ministry of Health. The Ministry of Health is the main provider of all health services for Saudis, residents and visitors. The Ministry of Health was established in the Kingdom of Saudi Arabian 1343H/1925, King Abdul Aziz established the Public Health Department in Makkah Al-Mukaramah. In 1344H $\backslash 1925$, Public Health and Ambulance was established to meet the needs of the Kingdom's health and environmental sectors. The PHA built hospitals and health centers across the Kingdom and issued and enforced regulations to guarantee adequate standards for the practicing of medicine and pharmacology. The increasing scope of healthcare services needed in the Kingdom during that period, including care for Hajj and Umrah performers, created the need for the formation of a Public Health Council. This council was the highestlevel supervisory board in the Kingdom, and oversaw all aspects of healthcare, including all hospitals and healthcare centers nationwide. The council's main goals included the development of a skilled healthcare workforce, as well as the control of the diseases and epidemics which were prevalent during that time. Eventually, it was necessary to create a large-scaled, specialized organization to carry out the Kingdom's health affairs. Royal decree Num. 8697 $11 \backslash 5$ was issued on 26-8-1370H \} 1 9 1 5 \text { and established the Ministry of Health. (moh.gov.sa). }

\section{1-1-1 The Concept of Privatization:}

Privatization is a broad and large concept appears in the United Kingdom in the early 1980s and has no specific definition but has many and comprehensive definitions. Some researchers believe that it means efficiency in the management and operation of public projects, increasing on market mechanisms and decentralization and bureaucracy. The concept here goes to the tools of the project in accordance with the contracts of management by 
the private sector while preserving state ownership of projects such as hospitals in the health sector and hotels in the tourism sector... etc.

In the opinion of some researchers, the concept of privatization is more comprehensive and reflects the concept of economic dependence on countries to affect the economy by rationalizing spending on some sectors, as well as improving services to the groups concerned and improving the working environment for employees. According to, Suleiman (1990), the privatization is transfer of decision making authority, delivery, or financing from a public to a private entity. Kettl (1993); Dilger et al. (1997) defined it as such shifts may occur by directly contracting out services to the private sector or may result indirectly from other arrangements, including partnerships with private sector. Sclar (2000) sees that the privatization approaches are based on the promise that the private sector can deliver services more effectively and efficiently than the public sector. In the context of health services, the concept of "privatization" is equate with reduce levels of public provision, subsidy, or regulation of either preventive or curative health services. The emphasis on provision, subsidy and regulation is particularly important given privatization is mostly associate only with the private provision of public services. However, privatization in health care often includes a broad range of arrangements (contracting-out, contract management, and load-shedding) rather than sale of public assets to the private sector. Indeed, it has been argued that health care privatization rarely entails the sale of an entire health program to a private fee-for-service provider. 1-1-2 The Objectives of Privatization:

In a study done by, Hadizadeh (2010) that the objectives of privatization are divide into two groups primary objectives and secondary objectives. Summarizes the primary objectives accordingly: Reducing the direct operation of the government in the economy, Increase capacity for job creation and efficiency of state-owned enterprises, Development of internal capital markets and access to foreign capital, technology and financial resources, Receive government revenues to cover the budget, costs, release of the budget of the corporate financial load leading to loss and reduce the amount of domestic and foreign, and Public sector liabilities. Also the secondary objectives of privatization are sets out as: Increase the participation of people in economic affairs Make the right decision as well as distribute the income through the distribution of shares among people, Develop job creation and creativity to prepare reasons, Enhance the productive capacity of the country's economy, Reduce government budget costs relate to reimbursement subsidies as well as reducing capital costs to cover under unite, Optimize the resources of the country on the basis of Market function, Improve trading conditions through the development of companies privately owned and finally promote knowledge in National level, and Providing capital resources for the economy and achieving balance between savings and investment.

The researcher sees that, the final message of the objectives of privatization is competent effective use of resources through allocation of resources to the market mechanism to achieve efficiency in competition and reduce the financial load of government.

The determination of the varies privatization objectives according to the progress of countries and their growth or if they are still classified from developing countries where the main objective of privatization in developing countries is to try to remedy economic crises through economic stabilization programs and structural adjustment.

Many developing countries have been forced by the international financial institutions, especially the World Bank and the International Monetary Fund, to adopt economic stabilization and structural adjustment programs to address the economic crisis that swept most of these countries in the early 1980s. These structural adjustment programs are a package of economic policies that may differ slightly from one country to another but usually include the withdrawal of government subsidies on goods and services and public sector institutions, the liberalization of prices of goods and services (price liberalization) and the devaluation of the national currency (Currency devaluation), reducing government spending (Govt.), Adding to the reduction of foreign exchange controls, the liberalization of interest rates to be real, as well as ending the non-tariff protection enjoyed by the local industry (Trade Liberalization) ), Tighten credit control, encourage the private sector to drive economic development, and so on To make way for it in all sectors that were the monopoly of public sector institutions and this is known as privatization (Hanke,1987.

Also, Jeffery (2000) Believes that one of the most important objectives of privatization is its importance by encouraging competitors, which results in better products and customer services, whereas state-run economies tend to be inefficient and bureaucratic. Today, failed state-run economies, improved systems of communication, increasing tax burdens and the basic human nature to strive for success provide some of the reasons leading to the trend of decentralizing world economies, such as those in Eastern Europe. So, this means that privatization is an integral part of the policies of economic reform and structural adjustment programs. It aims mainly at addressing the economic crisis by correcting the negative impact of the financial performance of public sector institutions on the public budget balance by reducing financial support and increasing its revenues, in addition to raising the efficiency of the private sector, assuming that the private sector is more efficient than the public sector, thus increasing the economic growth rate of the country. Satisfaction Within communities, as well as to improve the administrative way and implementing non-traditional ways and thus create value for institutions and organizations 
can through it to be in the ranks of developed countries if they plan and well execute.

\section{1-1-3 Methods of Privatization:}

Privatization has different methods and each has advantages and disadvantages. Choosing the right method is one of the most important elements of successful privatization. This choice depends on a number of elements, the most important of which are: the objectives of privatization, size of the companies to be privatized, the extent of the development of financial markets, and the characteristics of buyers and investors. Privatization methods can be categorized into and designated. Namely: the methods that terminate State ownership and lead to the transfer of assets to the private sector and those that do not terminate this ownership. The success of privatization in countries depends on good planning and implementation strategies and the choice of the appropriate form and method of privatization to achieve the desired objective and the methods of privatization. Dzakpasu (2000) classify forms of privatization as follows: "Divestment - sale, free transfer and liquidation; Delegation - contract, franchise, grant, voucher and mandate; Displacement - default, withdrawal and deregulation. It is also one of the major mechanisms by which an overextend state reduces its direct involvement in the economy. It may take any of the following forms: full or partial sale or transfer of ownership; sale of assets; leasing arrangements; contracting out; liquidation of enterprises. In terms of the appropriate form of privatization of the health sector, a vast number of studies have addressed the PPP (Public Private Partnership) as either a form of privatization or another model of managing healthcare facilities and controlling resources. Moreover, there are misunderstand-captions and confusion about the meaning of " privatization " and " contracting " (Villa, and Kane. 2013). Privatization involves changing the identity of an institute; the contracting of an institute focuses on its external relationships, Perrot (2012) or contract periods (short or long) (Norment, 2010). Other studies have distinguished between pure full privatization and partial privatization. Partial privatization signifies that not all assets are transferred from the government to private ownership: the government retains some of the ownership. (Braithwaite, et al., 2011). Still other investigations have use " privatization " and " equitization " interchangeably; although in some cases, " equitization " is used to mean " privatization of assets ". (Braithwaite, et al., 2011). In this respect, hospital asset ownerships (land, buildings, etc.) transfers from the government to the private sector. In addition, there is confusion in the distinction between privatization and corporatization." Corporatization " has been understood to signify the reorganization of a government or semi-government agency so that it is able to operate in a financially responsible way. (Braithwaite, et al., 2011).

Therefore, the entity that adopts and prepares privatization plans and strategies should take into consideration the nature of its work, the services provide, and with whom it deals to determine the optimal form of privatization. choose the concepts clearly, not mix the terms and the precise choice of the method of privatization to be implement and make sure it is clear to all parties concern because the wrong understanding of the process and ambiguity in choosing the best method for privatization may lead to confusion and doubt in the implementation and the difficulty of linking With the goals thus failing to implement and obstructing the whole process.

\section{1-1-4 Privatization between Obstacles and Benefits:}

In a study of Albreht (2009) believes that privatization began as a political slogan and its consequences are not clear and that privatization is considered one of the processes that are not black or white but carry different degrees of gray! The most important obstacles according to (Albrehat, 2009): Challenges in the equities, especially when the introduction of large personal expenses in the replacement of public expenditures (such as alternative insurance). Also, the challenges of transparency in the case of the private service provider provided only on the basis of the effective use of financial materials and not based on the results and the development of health care systems available to people who have the ability to pay. In addition to unclear regulations: an appropriate regulatory system must be created by the country to give each patient the right to receive treatment while ensuring quality of care, which in principle should be independent of the individual's ability to pay. According to study done by Al-Buridi (2008), The decision makers in the public sector, especially in developing countries, have a weakness in the organization and clarity of the process, which makes it an obstacle to the implementation of privatization technology. He points out that some countries have already begun privatization for some time, but soon the front of the problems and that because of misty vision and not to study properly and not to deal well with the parties resisting it. It is also mention that because of the complex nature of privatization, its implementation process requires very lengthy procedures, so some countries resort to institutional organization, such as the WBIMF, to prepare research and studies of the state and also to support its implementation. Al-Ali (2002) study is consistent with previous studies, he adds that there are many obstacles and challenges facing privatization, and it is important to pay attention to them. The most important of these are: the problem of legislation and regulations, administrative difficulties, lack of develop financial markets. In addition to the fundamental problems raised by privatization as, the problem of employment in public institutions: this is one of the most controversial topics between supporters and opponents of privatization, where there is a problem in the future of workers and workers in projects and the researcher attribute this fear because of the existence of convincing unemployment mainly in most public institutions and the existence of a large number of inefficient employment. Alongside the obstacle in the desire of the private sector to invest in good public institutions Situation: This type of thinking increases the burden of the 
state in the restructuring and reforms of institutions faltering because of lack of interest and the search for successful projects that achieve significant profits and phenomenon. However, many studies and researchers believe that privatization has high weight bearing benefits on the country as a political, economic and social force. This makes the country among the developed countries because it achieves the best distribution of financial, human and technological resources and improvements. In the efficiency of operations and help attract investors (Omran, 2004). A study conduct by Lewis, et al. (2009) show that the best benefit of privatization is the good distribution of resources. It increases profitability and efficiency in both competitive and monopolistic sectors, and also confirms that full privatization is more beneficial and more successful than partial privatization. Boardman, et al., (2012) say most of the privatization operations in Canada over the past ten years proved to be successful and had a largely positive overall impact. Economic indicators such as capital expenditures, dividends, tax revenues and sales were on the increase for each employee. Most of the privatized enterprises were operating highly efficient.

According to a study conduct by Cinar and Eren (2013) in Turkey, the efficiency and efficiency of the administration increase significantly after privatization in the management of health care services. A study by Claessens and Djankov (2002) link privatization with a significant increase in sales revenues and labor productivity, and to a lesser extent with fewer jobs. The positive benefits of privatization are stronger in terms of economic size and statistical importance over time. In view of the previous studies mentioned above, we find that it is unanimously agree that the benefits of profitability, productivity, efficiency and economic efficiency are the main characteristics of the benefits of privatization, social benefits and society in general. There are several questions and few studies whether privatization as a successful and useful operation has done its part social responsibility, improvement of provide services and community satisfaction.

\section{1-1-5 Privatization Experiences in Saudi Arabia:}

The concept of privatization began in Saudi Arabia at the beginning of the 1970s when the five-year plans for successive development were announced. These plans were adopted in 1970 and the main objective of the government was to develop and stabilize the economy (Al-Buridi, 2008). The first step toward implementation of the privatization of the government started with the introduction of $30 \%$ of SABIC's private sector capital. In the Sixth Development Plan (1995-2000), the strategic basis for making the private sector more widely available was national development. The privatization of funding through the mobilization of private savings and directing them to finance public projects, the privatization of production through the granting of management and operation contracts for public projects, the privatization of ownership through the sale of some government assets in the shareholding companies gradually, and continue to liberalize economic activity and improve the investment environment. In mid-2002, the Supreme Economic Council endorsed the privatization strategy and defined the policies, objectives, areas, controls, steps and priorities of the targeted activities (Alaamri and Alghanim, 2011). Proposals and studies to privatize some sectors have been rolled out because officials believe that it will contribute effectively to rationalizing spending and improving the organization in general, including the privatization of Saudi Airlines, the transport network and the Saudi Electricity Company (Al-Ghamdi, et al., 2004).

In the health sector, privatization has started as a partial privatization linked to a direct link with the Ministry of Health. This was based on proposals and reports submitted by committees to the Ministry of Health, which include a detailed description of the status quo and suggestions for improvement and upgrading of employment in the health sector. The privatization of the health sector is not considering the birth of a moment or a new idea, but rather the result of studies carried out by the ministry and some of them have already been applied to some parts and departments of care and health services.

And after the announcement of the privatization program within the vision of 2030 it become a formal and mandatory on all sectors to begin to develop plans and strategies to start implementation in a holistic rather than a partial.

The Saudi Health Sector privatized in part and in several stages and took several forms and pictures including: First, Through tenders and contracting: where the Ministry of Health to announce a specific project or service wants to be privatize by the private sector locally or internationally and then review the offers conforming to the standards and require conditions by the Ministry on the companies bidding for the tender and the award of the lowest price, And the conditions stipulated, and the projects contracted by the Ministry of Health for the privatize of companies maintenance services and operating and cleaning and security. As well as food finance companies for inpatient patients. The company provides all the food base on reports from the hospital according to the patients' cases and is under the direct supervision of the hospital nutrition department. Second, Outsourcing Services: Within the plans of the Ministry of Health to rationalize health spending and to reduce the pressure on public hospitals central has so-called outsourcing services as a kind of privatize of some of its facilities, including dialysis centers as they follow the same steps to announce the contracts, but leave the administrative matters also to the same company. Third, Self-Employment: In this form of privatization focuses on the independence of the management of public hospitals and employment and make the work takes the institutional framework away from the bureaucracy of the government and follow by a pay scale and private recruitment mechanisms. Forth, The partnership between the public hospitals government and private hospitals: Where the Ministry of Health launched 
in 2014 a program called(Ehalati "Referral-to") this program along with other services, but it helps public hospitals to search for private hospitals in case the hospital wants to send a patient due to lack of beds or the absence of a place in the room or the intensive care unit is refer to the nearest private hospital in the absence of a public hospital available to receive the case. The private hospital covers all the needs of the transferred patient and the ministry pays the costs of the private hospital. There are requirements and controls that must be applied by the private hospital, such as having a certificate from the Ministry of Health (CBAHI ), to be register within the reference hospitals in the program (Ehalati), to submit periodic reports to the Ministry on the status of the hospital and the services provide.

\section{1-2 Problem Statement:}

In today's competitive world, most of the world countries are struggling to find the best health care models. This struggling did result in different health care systems some are purely governmental, some are relying on privatization system and some are having mixture of both. There is no doubt that the tremendous cost of any health care system does put a huge pressure on the governments, and their annual budget. Because of those reasons and the rapidly rising population, KSA government represented by ministry of health decided to move forward with privatization as a model of health care system. It is important to say that the health care system in KSA is mainly governmental where the Saudi patients have a free access to this system till now. And also the consideration the major challenges for Health Ministry is to provide unique and high standers medical care in Umrah and Hajj season. This study will try to find out if privatization is the best model of health care and what are the pros and cons of applying if focusing mainly on the decrease spending of the government for health care, improve management system, and generate a stranded healthcare system that will satisfy recipients of health services.

\section{1-2-1 Objectives of The Study:}

This study aims to achieve the following objectives:

- To know how effective this step is on the health services sector and hospitals

- To study the impact of privatization on selected factors that could have a role in promoting the success or failure of the privatization process.

\section{1-2-2 Research Questions:}

This study seeks to answer the question of (How does privatization impact on Saudi health sector?). Thus, the following questions are needed in the examination:

1. What is the impact of privatizations on the government spending on the health sector and hospitals?

2. What is the impact of privatization in improving services provided to citizens?

3. What is the impact of privatization in management improvement?

4. What is the impact of privatization in improvement of the working environment of health practitioners?

\section{1-3 Importance of Study:}

The Kingdom of Saudi Arabia has always emphasized the importance of providing excellent health services with high standards and universality to citizens and residents and to satisfy all beneficiaries of health services. In order to achieve this, the government has decided to undertake the process of privatization in order to achieve this main demand in the health sector. As well as to improve the stereotype in the management of hospitals and health facilities and provide a good working environment for health practitioners, which helps them to provide better services. On the other hand, the government believes that the privatization of service sectors increase efficiency and remove from the centralization and reduce the financial burden on the budget of the government. In this study, the sample responses will be identify and analyse to view their ideas and opinions about the privatization process. This study is of great importance in enriching the knowledge side, especially since studies in this field are relatively few in Saudi Arabia. Finally, it is necessary to know that the process of privatization is not an easy process but rather a complex process that requires a thorough and detailed study from all sides, comparing its advantages and challenges to the process of privatization and developing a strategic plan for this before implementing privatization.

\section{Chapter Two: Literature Review}

Privatization is a key segment of development programs in both developing countries. The objective of such projects is to accomplish higher macroeconomic productivity and encourage financial development (Akinci, 2002). The impact of Privatization on health sector and other countries' sectors are investigating by several researchers for many years and in different countries around the world, in which the majority of those studies clarified that there is a positive impact of privatization on both monopolistic and competitive sectors regarding the sector's profitability and productivity increment, reduction of spend, management improvement and beneficiaries' satisfaction. However, the distinction between these studies revolves around the dependent variables chosen by each study for the purpose of measuring the impact of independent variable (privatization) on them, as well as the sector and country that have investigate and research, which vary between the health, banking and other sectors, whether in developing or developed countries.

One of the studies that investigate the impact of privatization on the satisfaction of beneficiaries done in 
Jordanian Cement Company by Jresat (2012). The study investigates the impact of privatization on the performance of company's human resources in terms of employees' salaries and incentives increment and employees' efficiency. The dependent variable is the company's human resources' performance and the independent variable is the privatization of the company. The researcher hypothesizes that privatization affects the efficiency of the employees positively and contributes into increasing their salaries and incentives. Therefore, in order to test those hypotheses, the researcher utilizes the analytical descriptive method as well as the practical one in which a questionnaire that designs by him distributes to 214 employees of the cement company in order to collect the required data. The validity and reliability of the questionnaire testes before being distribute utilizing Cronbach Alpha measurement. The reliability value was $90 \%$ which implied that the questionnaire has high reliability and acceptable to be applied. The collect data was analyzed utilizing different statistical methods including percentages and frequencies, and the ordinary least square regression analysis. The obtain results indicate that there is neutral impact of privatization on the employees' performance as well as their salaries in the company. Moreover, the results also indicate that there are no statistical differences between the impacts of privatization on the performance of employees attributed to the demographic variables. Finally, the researcher recommends the subsequent researchers to investigate this impact deeply by including the employees' years of experience as an additional variable in their future studies.

Moreover, and for the similar purpose of the previous study which aims to measure the influence of the privatization on the beneficiaries' satisfaction, a study done by Al-Mutairi et al. (2014) aims to investigate the attitude of employees and managers towards privatization programs in Kuwait. The researchers endeavor to explore the extent to which employees and managers of privatized companies agree or disagree with different aspects of privatization including the forms of privatization, its obstacles, fields, motives and factors that facilitate it. The independent variable of this study is the privatization and the dependent variable is the extent of employees' agreement or disagreement with the previous mentioned aspects of privatization. In order to achieve the aims of the study, the researchers utilize the analytical descriptive approach in which they design a questionnaire that was consisted of six sections; each section for each aspect of privatization. This questionnaire distributes to a sample of 400 employees and managers of 21 privatized companies under Kuwait Investment Agency (KIA). 238 questionnaires were returned out of the 400 with a $60 \%$ response rate. The questionnaire's reliability and internal consistency also teste by Cronbach Alpha coefficient and a value of 0.938 was obtained which means that the instrument has high reliability and can be utilized. The collected data was analyzed through different descriptive statistics including percentages, frequencies as well as Kruskal- Wallis coefficient for the purpose of measuring the levels of employees and mangers' agreement or disagreement with the different aspects of privatization. The analyze data reveal into an agreement between the employees that a successful Kuwaiti privatization programs ought to be limit to deregulation, outsourcing and joint project partnerships types of privatization. The results additionally demonstrated that privatization process would encounter several difficulties because of the absence of profit incentives and competition in the ventures of the public sector and that privatization may result in workers' lay-off and fear of broad government regulation. Moreover, the researchers state that employees and managers agreed to the concept that the privatization process should be limit to small and moderate ventures only, such as, communication and luxury services and goods. However, the government should keep being in charge of some key countries' ventures, such as, health, education and water. Finally, the researchers indicate that the chosen sample agreed that effective privatization would lead to improvement in the quality of services, development of Kuwaiti economic relations as well as the Kuwaiti investment climate and competition which would contribute positively to Kuwait economic growth.

Another study that also concerns about studying the impact of privatization on the beneficiaries' satisfaction is a study of Ram and Prabhakar (2011). The study examines the impact of privatization on the job satisfaction of telecom company' employees in the public sector of Oman. The dependent variable is the employees' satisfaction which is dependent on the independent variable which is the privatization. To achieve the objectives of the study and test the relation between the dependent and independent variables; the researchers utilize the descriptive analytical approach in which they collect the primary data through an Employee Job Satisfaction Questionnaire consisting of 25 statements. The questionnaires were distributed, after testing their reliability and validity by exploratory and confirmatory factor analysis, to 65 randomly selected employees from different departments of Omantel. The relationship between employees' satisfaction and privatization was then tested by applying statistical regression analysis on the collected data. The entire privatization quality dimensions existed in the questionnaire indicates a strong impact on the satisfaction's level of the chosen employees. So, the study revealed that most of the sample's members are satisfied with their job after the privatization of Omantel Company compared to the situation before privatization has been occurred. The researchers explain this by the recent renewed Omani interest in public sector performance as long as they face a more competitive global environment. Finally, the researchers suggest for future studies to test the relation between privatization and other variables including tardiness, productivity and absenteeism. So, it could be recognized that this study is also similar to the current study in testing the impact of privatization on the satisfaction level of beneficiaries which is represented by employees' job 
satisfaction in Ram and Prabhakar's study.

Moreover, the impact of privatization on the human resource performance (considered as privatization's beneficiaries) has investigate by Esfandiari et al. (2011). The study aims to examine the impact of the independent variable (Privatization) on the dependent variables of human resource performances and the role of the State in public Enterprises. The researchers review the theoretical literature and made an empirical analysis through a survey (questionnaire) that measures the performance of workers before and after privatization. The performance measures are (labor productivity, operating efficiency, output and HRP).the results indicate that the outsourcing and privatization on the human resources performance in the public sector have been noticeably nuanced and complex than it seems. Particularly, they found that privatization has been connected with instability and complexity in labor's performance in the public sector, especially as it has seen as a risk factor that cause job insecurity and a threat for negative self-rated performance. Therefore, they conclude that privatization, unlike what have thought, and has negative impact on the human resources performance measures. The researchers recommend conducting future empirical studies that would differentiate the effect of outsourcing and privatization on Iranian HRP. This study is similar to the current study in testing the impact of privatization on the satisfaction level of beneficiaries (Human resource performance); however, it might be different than the current study in the positivity or negativity of its impact as long as this study is one of several studies that consider a negative impact of privatization on the performance.

Furthermore, another study that conduct by Ram (2012) aims to measure the impact of privatization on the same variable that is the satisfaction of beneficiaries. In this study the researcher concerns about observing the impact of privatization on the job satisfaction of a sample of 51 employees who were working in a privatized public telecom company. He utilizes an analytical descriptive approach to test the study's main hypothesis which is assuming a positive impact of privatization on employees' job satisfaction. The primary data was collected by a job satisfaction questionnaire that its validity has been tested by confirmatory factor and exploratory analysis. The results show that most of members are satisfy with their job after privatization compare with the situation when it was a public organization which means that there is a positive impact of privatization on employees' job satisfaction. The researcher recommends studying the impact of the same independent variable which is privatization on other dependent variables such as productivity, absenteeism, tardiness and customer satisfaction in the future studies.

The work environment and climate represent another variable in which privatization's effect has widely explore. One of the previous studies that examine this effect is a study of Falkenberg (2010) in which aims to explore the effect of privatization and corporatization on employees' work attitude and work climate. The dependent variables of his study are (work climate and employees' attitude) and the independent variable is the privatization process. The researcher follows a systematic literature procedure (descriptive analysis) in which critically analyzes three previous empirical studies that utilize questionnaire data from Swedish acute care hospitals in them. The researcher concludes that according to the first analyzes study, the physicians at privatized hospitals have express more positive experiences of their work climate compare to those who are working in public hospitals. Moreover, from the second analyzes study, he observes that privatization has more negative implications for center hierarchic level workers who revealed deterioration of work attitudes, while there were no real ramifications for physicians or assistant nurses (high or low hierarchic levels). Furthermore, the third study finds that in spite of the fact that the work circumstance for ladies and men doctors were to some degree practically identical the majority of the distinctions that stayed between the sexes were to the inconvenience of ladies. Finally, the researcher concludes that privatizations do not imply essentially negative impacts to employees' attitudes and performance, rather it depends on the employee's ability to adopt the requirements connected with privatization organizational change.

Swai's (2014) another study that also investigates the impact of the interdependent variable privatization on the dependent variable work environment and climate in which the researcher endeavours to investigate the impact of privatization on the employees' quality of work life. The researcher utilizes mix methodology through the adoption of qualitative research design (Rapid Assessment Methodology) and the quantitative analysis (questionnaire's survey) of a sample study of 340 workers working in Tanzania Breweries Company Limited (TBL) and Tanzania Electricity Supply Company (TANESCO) as both of these companies represent Public Private Partnership (PPP) and Management Contract modes of privatization. The collected data was analyzed by different statistics approaches including percentages, frequencies and regression analysis. The researcher finds that privatization has significant positive impact on employees' quality of work life regarding the work conditions, attributes, supervisors-employees' relationship and safety and health conditions. Privatization also contributes in positive effects on the services accessed to employees and the improvement of HRM relations with employees which resulted in a more comfortable working climate and employees' higher quality of work life. On the other side, the investigation revealed that the conditions of work have become more precious and described by stress, heavy work load and strict work schedules. Finally, the researcher recommends a future study in the same field and interest, but with a larger sample of organizations in order to have a more reliable result.

Additionally, the economic situation (spending reduce) and management improvement represent other factors 
associate with privatization process. One of the studies that investigate the impact of privatization on the country's different sector economic situation is Kallianiotis's (2013) study. In this study, the researcher endeavours to investigate the impact of the independent variable (Privatization) on the dependent variables (economy, employment, financial markets, social welfare and national wealth) of Greece. The researcher utilizes the descriptive analysis in which he reviews several previous studies relate to different aspects of privatization in order to achieve the aims of his study. The researcher indicates that privatization process under control might result in increasing efficiency, liquidity and productivity of the financial markets of Greece. However, the privatization may lead to enormous unemployment, loss of social welfare, high dependency on multinational enterprisers and foreign capital as well as the loss of the national wealth which represent the worst effect of privatization. Moreover, he concludes that the maximum level of privatization is the one that maximizes the social economic situation, reduces the spending and doesn't eliminate the nation's wealth.

Another study that conducts by Yonnedi (2009) aims to examine the relationship between the privatization of State-Owned Enterprises and their organizational change, management and performance improvement in developing country context. The researcher utilizes the analytical descriptive analysis in which he distributes a survey questionnaire to 86 managers of 86 privatized firms and private companies. Through the cross-sectional analysis, it concludes that privatization brought about important alignments among the organization's goals, resources, design elements and its competitive environment. Privatization alters the behaviour, management, performance and incentives of formerly privatized company. Moreover, the researcher stresses the importance of leadership and management in the privatization's achievement and the need of training programs targeting the managers of newly privatized companies in order to improve their managerial skills.

A study by Çinar and Eren (2013) compares the effects of privatization on the management of public health organizations before and after the privatization process in Turkey; The independent variable is the privatization of the management of health care organizations, and the dependent variable is public health; The researchers adopt the qualitative approach, which relies on reviewing previous literature demonstrating the strengths, weaknesses, opportunities, and threats of privatizing the management of public health institutions in Turkey; The study shows a number of results, including that the strengths of privatizing the management of public health institutions mainly include the increase quality of health care services, thanks to competition and the lack of bureaucratic problems in management. Also, the weaknesses of the privatization of the management of public health institutions include the instability of the financial situation, the lack of government funding, and taxes. And, the opportunities offered by the privatization of public health institution management include addressing the problems associated with overall performance and innovation in providing better health care services. And the possible threats of implementing the privatization of the management of public health institutions include weaker social visions, increased focus on profits, weaker professional development programs due to the focus on the most profitable medical fields, and weaker accountability and transparency policies. The study sets a number of recommendations, including the following: Governments worldwide have to pay attention to the privatization of management only in any public health institution rather than privatizing the institution entirely in order to improve the implementation of privatization procedures and provide medical supervisors with a higher level of freedom; Additionally, it's important to take suitable measures to avoid any possible negative side effects of the implementation of this specific type of privatization.

All of the previous studies have investigated the impact of privatization on different countries rather than Saudi Arabia and on other sectors rather than health sector. However, for Saudi Arabia's privatization impact on different variables and barriers that hinders the application of privatization process in Saudi Arabia, in a study of Saaeti (2012) applies in the province of Jeddah in Saudi Arabia on the possibility of privatization of hospitals from the point of view of workers and beneficiaries of health services. The researcher believes that the government should be encourage to take the decision to privatize, even partially or at the level of management, and focus on improving the administrative level, relations and communications. This study concludes that the administrative level should be rehabilitate and awareness among employees about the concept of privatization due to differences and fear of vision of employees. As well as the impact of the process of privatization on the level of medical services provided in hospitals. However, for Saudi Arabia's privatization impact on different variables and barriers that hinders the application of privatization process in Saudi Arabia.

Al-Buridi (2008) conducts a study that concerns about investigating and analyzing the privatization program in Saudi Arabia with specific references to the process of applying the program. The researcher aims mainly to obtain the reasons for the delay in implementing the privatization program in Saudi Arabia and to investigate the barriers that hinder the implementation process as well as developing an efficient model to help the Saudi government in facilitating the implementation of privatization program. Therefore, the researcher utilizes the analytical descriptive method, through reviewing the literature and surveying a group of private and public sector managers that represents a source of data for research. This research fills the gap of knowledge about management and planning of privatization in Saudi Arabia and shows the effective implementation process of privatization as well as efficient models to implement and manage it. The researcher concludes that the privatization program in 
Saudi Arabia face a limit commitment from the government which decrease its implementation speed, the management structure also created obstacles to the implementation of the process and there are different problems that affected implementation process including employees' attitudes in public sector as well as restricting of different enterprises and applying different legislation and regulations. Furthermore, he discovers that in order to improve the privatization implementation in Saudi Arabia, three models should be apply which are: employee model, restricting model and regulation model.

Onour (2012) also conducts a study that explores the challenges and issues confronting the implementation of privatization strategy of Saudi Arabia. The dependent variables of this study are the issues and challenges facing the Saudi privatization process and the independent variable is the privatization process itself. The researcher utilizes descriptive approach as a researching method in which he reviews the previous literature and studies to obtain the related number of issues and challenges facing the implementation of privatization in Saudi Arabia. He concludes that the main challenges and issues are: the debt issue of public enterprises, valuation of public enterprises under imperfect capital market, securing efficient tendering process, labour issues and land use restrictions, and a corporate governance system that control and direct the behaviour of management after privatization. Therefore, the researcher highlights the importance of having a good Saudi corporate governance system that effectively control and direct managerial behaviour towards improving and privatizing the business.

A Study by Al-Ali (2002) about the impact of privatization on the attitudes of managers and their assistants in governmental hospitals in Jordan. Where the researcher uses the quantitative descriptive approach, the researcher distributes questionnaire to 1383 administrative group in 23 governmental hospitals in Jordan to study the independent variables of administrative and legal factors and the dependent variables of the managers ' attitudes in the privatization process. The study concludes that there is a positive tendency on the part of the administrators to privatize and the results are based on this study that privatization gave greater freedom and administrative autonomy to managers and health sector services in Jordan the study recommends the privatization of the public health sector in order to achieve increased efficiency and improved The level of health services provided and make the work more flexible and easy.

Another Saudi study that has investigate the attitudes toward the effect of privatization on the employment system of Saudi Arabia is Al-Modaf's (2003) study. In this study, the researcher aims to investigate the attitudes of Saudi undergraduate college students toward the expect effects of privatization on the Saudi privatized SOEs' employment system. The researcher utilizes analytical descriptive method in order to satisfy the study objectives through which he distributes survey questionnaire in to 672 Saudi undergraduate college students. He concludes that there is a large of varied attitudes of respondents towards privatization effects. Large percentage of the sample prefer working under close supervision of Saudi management, gaining a salary that is associated with their productivity, being promoted based on performance rather than seniority and being adhered to prescribed method in implementing job tasks which represent the main aspects of privatization. However, another large percentage of the study dislike the idea of putting forth more effort to meet management's plans and of compromising job security in return of high salary. Moreover, the researcher discovers that while the majority of respondents believe that the privatization of state-owned enterprises is better for the local economy, their support for privatization is qualified by their determination or desire not to adversely affect their own interests.

Moreover, Alroqy (2010) conducts an exploratory investigation into the impact of privatization on another variable rather than attitudes, performance of workers or the other previous mentioned variables. He investigates the effect of privatization policy on the management accounting control systems' (MCS) improvement of two Saudi selected privatized organizations. The study explores the nature of control systems before and after privatization in order to understand the impact it has had on the selected companies. It also investigates if privatization is the only reason of change or if there are other influencing factors. The dependent variable of this study is the management control systems' improvement and the independent variable is the apply privatization policy. The researcher conducts a case study in order to investigate the required effect of privatization on the MCS's improvement of two Saudi organizations that have been privatized recently which were Saudi Electricity Company and Saudi Telecom Company. This case study is conduct utilizing qualitative approach in which semi structured interviews have conduct with companies' employees, classify official corporate documents have been also review and another semi structure interviews have conduct with an external relate party which is the Saudi Investment Authority. The researcher analyzes the collected data by content analysis in order to achieve the required results. The study find that privatization cannot change companies' MCSs alone, rather the achievement of such a change in MCSs of companies required changes in cultural and external environment alongside with making organizational changes. However, the study indicates that there is a noticeable positive impact of privatization on the MCS of investigate companies, but this impact would be different between companies according to the degree of competition, managerial power within the companies and the degree of government involvement.

Furthermore, another several studies have conduct in order to investigate the impact of privatization policy and process on the health sector of different countries. One of those studies is the study of Tiemann and Schreyögg 
(2012) in which they aim to investigate the impacts of privatization on Germania hospital efficiency. The independent variable is privatization and the dependent variable is the hospital efficiency in which it measures based on the contribution of applying privatization on the hospitals' spending and expenditures and the quality of healthcare provide by the hospitals. The researchers apply an analytical approach in order to achieve the aims of their study. They utilize boot-strapped data envelopment analysis (DEA) efficiency scores and then apply a difference-in-difference matching approach within a panel regression framework in order to analyze their data. After they complete the data analysis, they discover that the conversion of public hospitals and healthcare facilities into private for-profit status ones contributed into increasing the efficiency of them to $2.9 \%$ and $4.9 \%$. This increment in the efficiency achieves due to the reduction of expenditure on supplies as well as the decrement in labor and staffing ratio in hospitals, except physicians and administrative staff, through the privatization process. However, they also clarify that hospital mortality input after privatization do not support frequently voiced concerns that the gained efficiency after privatization are realize at the expense of quality of care. In contrast, the healthcare quality would be developed after the privatization. Therefore, they recommend that privatizing public hospitals would be an effective way to cut off extra spending and ensure the best allocation of resources in the health-care sector.

Guimarães and de Carvalho (2011) also conduct another study that endeavor to review the different impacts of privatization and outsourcing in healthcare sector. The researchers conduct a theoretical systematic review for several literatures (descriptive analysis) in order to draw up a conceptual understanding of the privatization impacts on this sector and provide a structure frame of outsourcing in different healthcare systems in different countries. The researchers investigate the privatization as an independent variable and the main drivers, activities, Benefits and risks of privatizing healthcare sector as dependent variables for Germany, UK, Australia and New Zealand, E.U.A and Greece. The result of this review study indicates that there is a lack of studies and researches that investigate and measure the impact of outsourcing and privatization on the healthcare sector. However, according to the review studies of those countries, it was obvious that the main common drivers for healthcare privatization in those countries were risk mitigation, spending reduction and adapting to quick developments and value stream redefining. Also, the main encounter risks of privatizing hospitals include the loosing of control over supplies, provide quality levels and loss of flexibility. Lastly, they mention that the main benefits of applying such a policy were the increasing of service quality, improvement of equipment and management, reduction in staff and cost as well as increasing the ability of accessing to best practices and top-class technology. This research is closely connecting with the current study in which it concerns about investigating the impact of privatizing on the spending reduction, management improvement and satisfaction of beneficiaries in Saudi hospitals.

In contrast to what is finding by most studies that privatization contributes positively in expenditure and spending's reduction, Waitzkin et al. (2007) investigate the effect of privatization on reducing out-of-pocket expenditures and improving the access to necessary health services in the health sector of less developed countries compared to what was observed by the World Bank and Wharton School. The dependent variable of this study is the out-of-pocket expenditures and the accessibility to privatized healthcare services and the dependent variable is privatization. The researchers utilize multi-method design in which they collect data from three different sources. Firstly, they reviewed previous studies, publications and literature related to their study; secondly, they conducted 42 semi structured interviews with different staff in insurance companies of the chosen less developed countries (United States, Argentina, Chile, and Mexico) and finally they assesse the companies' annual and periodic reports. The collect data analyze through content analysis. They find that the privatization through conversion of public insurance organizations into private ones or by expanding the organization through the participation of corporate entrepreneurs has not succeeded in improving the access to health services for vulnerable groups. Moreover, the study finds that privatization benefits in reducing expenditures are less than what is postulate by the World Bank and Wharton School. In brief, it concludes that privatization didn't improve the access to health services and didn't reduce out-of-pocket expenditure for poor people.

One of the other studies that its results support the results of Waitzkin et al. (2007), is the study of Davari et al. (2012). In this study, the researchers endeavor to investigate whether the privatization of public hospitals would contribute positively to improving the public hospital performance and outcomes and whether the current privatization in Iranian hospitals had helped in improving the hospitals' efficiency and patients' access to healthcare. The dependent variables are the patients' access to healthcare services, hospitals' efficiency performance and patients' protection from high cost services, however, the independent variable is privatization. The researchers utilize mix methodology in order to achieve the study's aims and objectives. Their mix methodology depends on conducting systematic literature review alongside with qualitative semi structured interviews with 38 participants from the healthcare delivery system and pharmaceutical division of hospitals in Iran. This triangulates with quantitative empirical evidences in the form of statistics in order to validate the interviewees' opinions. The results of this study identify privatization as a bad solution for supporting or assisting the healthcare system. The researchers also find that privatization doesn't improve the hospitals efficiency or the patients' access to healthcare services; rather it increases the direct patient payments and had a negative impact on patient access to healthcare. 
Accordingly, the researchers recommend against the healthcare's privatization.

Also, as a supporter for Waitzkin et al. (2007), and Davari et al. (2012) studies, Villa and Kane (2013) interest in investigating the effect of privatizing and assessing its impact on public hospitals of three American states (California, Florida, and Massachusetts). The researchers concern about investigating the impact of the independent variable (Privatization) on the dependent variables of hospitals which are (efficiency, profitability and community benefits). In order to achieve the aim of this study, the researchers utilize a quantitative longitudinal methodology in which they compared a three-year mean value of pre and post privatization hospitals. Then, the changes for each hospital's performance compare with a control group (nonequivalent group) of American public hospitals. The researchers conclude that American hospital privatization reduced patients' lengths of stay and increased occupancy and margins rates. However, it notices that privatization has negative effect on healthcare sector through which it increases the cost of services and reduce the access of patients to healthcare services which represents a negative impact on beneficiaries' satisfaction that is going to be study and investigate in this recent study.

Furthermore, Yip and Hsiao (2014) emphasize on the negative impacts of privatizing public health care systems. In this study the researchers tried to study and investigate the efficiency of Chinese government plans towards the privatizing of their public hospitals and to investigate the manner in which the China's health caresystem would perform after privatization. The researchers utilize the health care expenditure, direct cost of patients and quality of provided care as dependent variables that measures the succeeding in the objectives of the independent variable, privatization. The researchers utilize a review methodology in which they deeply and critically analyze the China's healthcare systems and their endeavours for privatization. The results indicate that privatization of Chinese health care sector would lead to an increment in the expenditure of health care system, population health outcomes' suffering, increasing patients' direct costs as well as the creation of two-tiered healthcare system in which the quality and access to health-care would be dependent on the payment ability. As a conclusion, the researchers stated that privatization has negative impact on expenditure reduction and beneficiaries' satisfaction. Therefore, they recommended china to enhance accountability, improve coordination over different healthcare levels and reforming the public sector as alternative effective solutions instead of privatization.

Hebrang et al. (2003) analyze some of the influences of the privatization process in primary health care in Croatia and, in particular, evaluate procedures taken by service providers (private companies) to improve their access to patients and the impact of privatization on the public health sector. The practices of privatization have been evaluated in two periods (1997/98 and 1999-2000) and the sample has been determined by regional intensity of practices and the status of privatization practices. Three sets of public practices have been included in the study, before, during and after the privatization process. The research conduct through an organized interview with public practitioners. The indicators analyses are: access to initial appointments, follow-up to visits, timeliness of visits, scheduling of visiting times, visits to the practitioner after hours, and access to telephone counselling after working hours. The study concludes that best practices that have been privatized have improved the access of patients to their services: they have made it possible for the patient to set his or her time, scheduled visits by telephone, to provide telephone advice outside working hours, and to reduce patient waiting times. The results of this research suggest that the privatization process stimulates practitioners to increase access to patients. This idea is documented in a health system based on national health insurance, where the allocation of funds depends increasingly on general practice. The changes relate to the accessibility of two aspects. One can be described as time-related accessibility (scheduling of first appointments and follow-up visits, and more precise dates for the appointment preset, schedule phone calls, honor scheduled times, and public perception of waiting time during visits to a practitioner.) The second can be described as expanding the range of services available, such as access to telephone counselling or availability after working hours. The study suggests that practitioners in the first phase tend to expand access through structural improvements that do not consume resources. It appears that service providers are adjusting the rates of access entitlements available according to the intensity of competition in the market. Further research is needed to accurately identify the set of structural adjustments that can be expected through privatization and to ascertain the impact of structural changes on the quality of care and health outcomes.

In Saudi health sector, a recent study conduct by Alkhamis (2017) in which reviews and critically analyzes the literature on healthcare privatization and its relation with access to medical care in Saudi Arabia. The dependent variable is the access to medical care and the independent variable is the privatization. The researcher utilizes a systematic literature review method to achieve the aims of his study. He firstly identifies more than 979 references related to his topic through a database search and additional 237 references from other sources. He then had taken only 11 articles after applying the exclusion criteria in which he excludes the ineligible articles. After the completion of systematic review for the included 11 articles, it concludes that there is weak evidence and low scientific validity supporting the argument that privatization would increase the access to medical care in Saudi hospitals. Finally the researcher recommends that before applying privatization on Saudi healthcare sector, hospitals and medical care centers should reform their healthcare financing including its efficiency and auditing. Also, after the privatization, they should develop a policy by which they ensure that most groups have access to 
good healthcare services despite the privatization's reduction in costs and staff.

A Study by Sibai (2001) entitled Health economics in the Kingdom of Saudi Arabia aims to explain the necessity of privatization of public hospitals in the Kingdom due to the increase in the volume of government spending on hospitals without improving the real quality of health care provided by government hospitals. The study expects that the population of the Kingdom in $1450 \mathrm{H}$ will reach about 30 million, as well as the expected actual increase in health care costs during that period.

The study of Alaamri and Alghanim (2011) identifies the attitudes of officials in the Ministry of Health in the Kingdom of Saudi Arabia towards the idea of the privatization of public hospitals and illustrate the major advantages and barriers related to the process of privatization; The independent variable is the privatization of public hospitals, and the dependent variable is the self-operating system; The study population consisted of all officials working in all hospitals operating under the administration of the Ministry of Health in Riyadh city in the Kingdom of Saudi Arabia; The study sample included (505) officials; The researches adopt the analytical descriptive approach, which relied on questionnaires; The study shows number of results, including that the study subjects were divided over the process of privatization; their attitudes were divided into supportive, optimistic, opposing, and sceptic. Also, the lack of adequate information about the process of privatization is the main reason why some study subjects were opposing or sceptic about the process of privatizing public hospitals. And the study subjects believe that public hospital privatization has several advantages, including higher health care service quality, increased accessibility, and equality in providing health care. And the study subjects believed that there are a number of obstacles facing the implementation of public hospital privatization, including increased costs, higher unemployment rates among health workers, and difficulties regarding moving public health workers to the private health sector. The study has a number of recommendations, including the following: The importance of setting the appropriate environment for the process of privatization; the importance of carefulness in implementing privatization without rushing; the necessity of speeding up the implementation of the processes of cooperative health insurance.

While a study of Alateeq (2002) aims to (1) investigate the Kingdom of Saudi Arabia's experience in transforming from the self-operating to the corporate-operating system, (2) explain the reasons why the Ministry of Health has moved to the corporate-operating system and the phases that this experience has underwent, (3) and evaluate the experience by identifying the major advantages and disadvantages; The independent variable is the privatization of public hospitals; The researcher adopts the qualitative approach, which rely on reviewing previous literature explaining the experiences in the Kingdom of Saudi Arabia in the area of transforming from the selfoperating to the corporate-operating system and the experience of transforming from the corporate-operating to the self-operating systems and the benefits the Ministry of Health is seeking through this policy; The study shows a number of results, including that transforming from the self-operating to the corporate-operating system had a number of advantages, including meeting the needs for high quality human resources in various medical fields, improving the quality of public health care services, and adopting modern paradigms of administration in public hospitals. And that transforming from the self-operating to the corporate-operating system had a number of disadvantages, including corporations' inadequate commitment toward hospital operating projects and a number of difficulties related to coordination like the inadequacy or delays in the allocation of funds. Also, the Ministry of Health started to transform from the corporate-operating to the self-operating system again for two major reasons; first, the need for the corporate-operating system is no longer present because the Ministry has achieved a high level of modernization of the public health sector; Second, the corporate-operating system is failing in several areas, including the "saudization" of the workforce and managing government spending. The study had a number of recommendations, including the following: The necessity of following a policy of moving from the corporate-operating to the self-operating system gradually, and that is to ensure that this process gradually remedies several problems relate to the contractual nature of the corporate-operating system, in addition to increasing the level of quality and efficiency in health care services.

\section{3- Research Design}

\section{3-1 Type of Study:}

This research studies use a descriptive quantitative approach to achieve its objectives and answer its questions. This approach is considered one of the most appropriate scientific study methods for this type of research. This study will enable me to investigate as many as possible members of the study community in Madinah society to find out the impact of privatization in health sector in KSA on dependent variables: rationalization of spending by reducing costs, management improvement, improving work environment of health practitioners, satisfaction of beneficiaries of health sector services .

\section{3-2 The Model Theoretical:}

The previous studies support the following theoretical framework that is shown in below figure. 


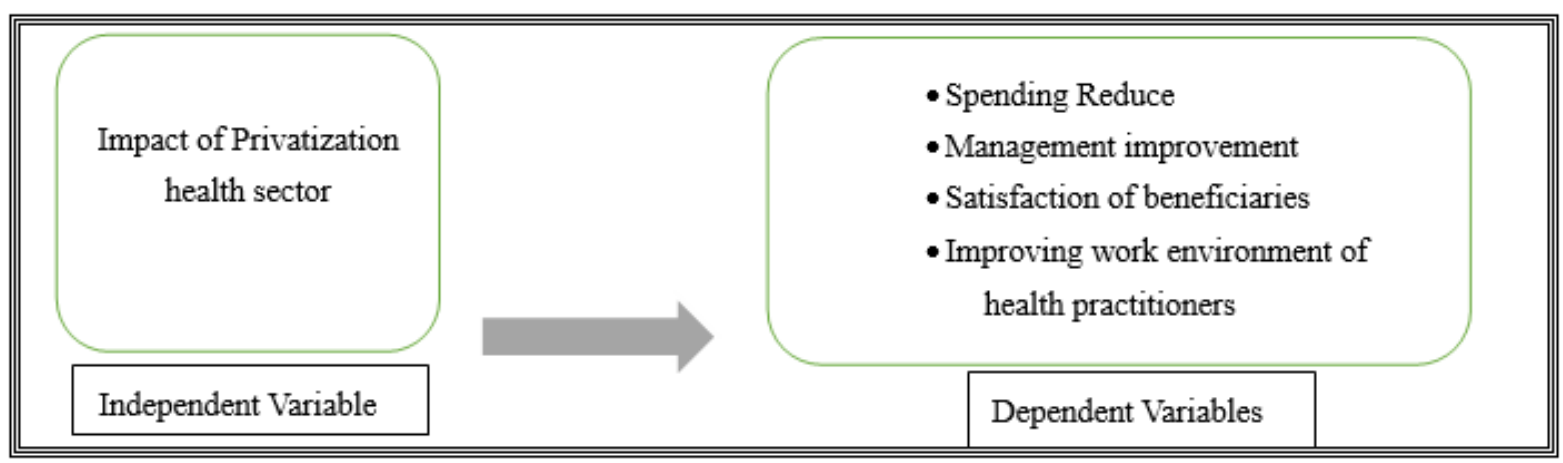

Figure 1: Theoretical framework

As Shown in Figure 1, the independent variable is privatization and its impact on four dependent variable rationalization of spending by reducing costs, improving work environment of health practitioners, management improvement, and satisfaction of beneficiaries of health sector services. And the influences in health care sector in Kingdome of Saudi Arabia.

$\mathrm{X}=$ Impact of privatization in health sector in KSA.

$\mathrm{Y} 1=$ Spending Reduce.

$\mathrm{Y} 2=$ Management improvement.

$\mathrm{Y} 3=$ Satisfaction of beneficiaries

Y4= Improving work environment of health practitioners.

\section{3-3 Definitions of Dependent Variables:}

- Reduce Government Expenditure: Government expenditure refers to the purchase of goods and services, which include public consumption and public investment, and transfer payments consisting of income transfers (pensions, social benefits) and capital transfer. Government spending goes to the nation's defense, infrastructure, health and welfare benefits. Rationalization government expenditure that means the government try to find to solutions to alleviate the financial burden.

- Improve Management: The exerted and continuous efforts to modify the processes, procedures, and administrative structures to increase productivity, efficiency, and increase the effectiveness of operations and contribute to raising the management skills of employees and thus improve the quality of services provided.

- Satisfaction of Beneficiaries: The degree of acceptance and conviction of the services provided by the Organization, and their contentment with the existence of the optimal services they need. The concept provides feedback about the quality of services provide by the organization directly from beneficiaries.

- Work Environment of Health Practitioners: Is the workplace in which the employees carry out their functions. The external work environment is meant to be a site, infrastructure and physical environment. It also means the internal atmosphere of work and the interaction of the staff with each other and with the processes, procedures, and work requirements. The health practitioners are the people or staff concerned to provide all medical services to patients within the health and medical facilities of all disciplines.

\section{3-4 The Hypotheses:}

Hypothesis 1: There is a positive impact of privatization the health sector on the government expenditure. $\mathrm{H} 01: \rho 1=0 ; \rho 1$ represent the effect of privatization the health sector on the government expenditure. "There is no effect of privatization the health sector on the government expenditure".

HA1: $\rho 1>0$ "There is a positive effect of privatization the health sector on the government expenditure".

Hypothesis 2: There is a positive impact of privatization the health sector on the management improvement. $\mathrm{H} 02: \rho 2=0 ; \rho 2$ represent the effect of privatization the health sector on the management improvement. "There is no effect of privatization the health sector on the management improvement".

HA2: $\rho 2>0$ "There is a positive effect of privatization the health sector on the management improvement.

Hypothesis 3: There is a positive impact of privatization the health sector on the beneficiary satisfaction. H03: $\rho 3=0 ; \rho 3$ represent the effect of privatization the health sector on the beneficiary satisfaction "There is no effect of privatization the health sector on the beneficiary satisfaction".

HA3: $\rho 3>0$ "There is a positive effect of privatization the health sector on the beneficiary satisfaction".

Hypothesis 4: There is a positive impact of privatization the health sector on the improvement of the work environment of health practitioners.

H04: $\rho 4=0 ; \rho 4$ represent the effect of privatization the health sector on the improvement the work environment of health practitioners. "There is no effect of privatization the health sector on the improvement the work environment 
of health practitioners".

HA4: $\rho 4>0$ "There is a positive effect of privatization the health sector on the improvement the work environment of health practitioners".

\section{3-5 Data Collection Methods:}

To collect the primary data which is the data relate to the field study, questionnaire will be use and will develop based on previous studies. The questionnaire will distribute electronically to sample categories, the questionnaire will use to collect data in this research to answer different study questions after building the theoretical background of the study in the field of privatization. The questionnaire consists of five sections: the first section is the demographic information, the second section contains statements about the most important benefits of the privatization, and the third section also contains statements about the most important difficulties facing the privatization process, the fourth section on the most important elements of the success of the privatization process. The fifth section contains a general question about sample members understand and approval of the privatization process. The questionnaire will build on the Likert scale 5 points where 1 (strongly disagree), 2 (disagree), 3 (neutral), 4 (agreed), 5 (strongly agreed).

\section{3-6 The Sampling Design:}

The sample of the study consists about (200) respondent from health practitioners and beneficiaries of health services in Madinah Society. The reason of choosing Al- Medina city is because of the increase in the population and because it is a holy city visited by a huge number of pilgrims annually.

\section{4- Data Analysis and Interpretation}

This section contains the analysis of data gathered from 200 respondent using SPSS 22 statistical program to analysis the independent variable (Privatization health sector) impact on several dependent variables (Spending Reduce, Improve management, Satisfaction of beneficiaries, and Improving work environment of health practitioners) and choosing the optimal statistical methods and appropriate to analysis this type of variables. Such as; Cronbach' Alpha, Frequency, Simple Linear Regression, and Factor analysis.

4-1 Coding of Demographic Characteristics:

\begin{tabular}{|c|c|c|c|}
\hline Variables & SPSS variables & Coding & Scale type \\
\hline Gender & Gender & $\begin{array}{c}1=\text { Male } \\
2=\text { Female }\end{array}$ & Nominal scale \\
\hline Age & Age & $\begin{aligned} 1= & \text { Less than } 30 \\
& 2=30-40 \\
& 3=40-50 \\
4= & 60 \text { and above }\end{aligned}$ & Scale \\
\hline Nationality & Nationality & $\begin{array}{c}1=\text { Saudi } \\
2=\text { Non }- \text { Saudi }\end{array}$ & Scale \\
\hline Educational qualification & Educational & $\begin{array}{c}\text { 1= High School or less } \\
2=\text { Bachelor } \\
3=\text { Postgraduate } \\
4=\text { Others }\end{array}$ & Scale \\
\hline Your occupation & Occupation & $\begin{array}{c}1=\text { Health practitioner } \\
2=\text { Administrative } \\
3=\text { Beneficiaries of health } 4=\text { Services } \\
5=\text { Other }\end{array}$ & Scale \\
\hline Years of Experience & Experience & $\begin{array}{c}1=\text { Less than } 10 \\
\quad 2=10-15 \\
3=15-25 \\
\text { 4= More than } 25\end{array}$ & Scale \\
\hline
\end{tabular}

Table 4-1: Coding. 
4-2 Demographic Characteristics of Respondents:

\begin{tabular}{|c|c|c|}
\hline Variable & Frequency & $\%$ of total \\
\hline $\begin{array}{l}\text { Gender } \\
\text { Male } \\
\text { Female } \\
\text { Total }\end{array}$ & $\begin{array}{c}89 \\
111 \\
200 \\
\end{array}$ & $\begin{array}{l}44.5 \\
55.5 \\
100 \\
\end{array}$ \\
\hline $\begin{array}{c}\text { Age } \\
\text { Less than } 30 \\
30-40 \\
40-50 \\
60 \text { and above } \\
\text { Total } \\
\end{array}$ & $\begin{array}{l}58 \\
80 \\
44 \\
14 \\
200\end{array}$ & $\begin{array}{c}29.0 \\
40.0 \\
28.0 \\
7.0 \\
100\end{array}$ \\
\hline $\begin{array}{c}\text { Nationality } \\
\text { Saudi } \\
\text { Non - Saudi } \\
\text { Total }\end{array}$ & $\begin{array}{c}176 \\
24 \\
200\end{array}$ & $\begin{array}{l}88.0 \\
12.0 \\
100 \\
\end{array}$ \\
\hline $\begin{array}{c}\text { Educational qualification } \\
\text { High School or less } \\
\text { Bachelor } \\
\text { Postgraduate } \\
\text { Others } \\
\text { Total }\end{array}$ & $\begin{array}{c}5 \\
90 \\
40 \\
15 \\
50 \\
200 \\
\end{array}$ & $\begin{array}{c}2.5 \\
45.0 \\
20.0 \\
7.5 \\
25.0 \\
100\end{array}$ \\
\hline $\begin{array}{c}\text { Your occupation } \\
\text { Health practitioner administrative } \\
\text { Beneficiaries of health services } \\
\text { Others } \\
\text { Total }\end{array}$ & $\begin{array}{l}65 \\
40 \\
108 \\
0 \\
200\end{array}$ & $\begin{array}{c}32 \\
20.0 \\
54.0 \\
0.0 \\
100\end{array}$ \\
\hline $\begin{array}{c}\text { Years of Experience } \\
\text { Less than } 10 \\
10-15 \\
15-25 \\
\text { More than } 25 \\
\text { Total }\end{array}$ & $\begin{array}{l}127 \\
32 \\
24 \\
17 \\
200\end{array}$ & $\begin{array}{c}63.5 \\
16.0 \\
12.0 \\
8.5 \\
100\end{array}$ \\
\hline
\end{tabular}

Table 4-2: Demographic Characteristics of Respondents.

The above table indicates that majority of the sample population $(55.5 \%)$ are female. Whereas the percentage of male are $(44.5 \%)$. The age group of the sample suggests that the participants base mostly range between 30 to 40 years old $(40 \%)$ and also detects that vast majority of them are Saudi $(88 \%)$. most of them have bachelor degree (45\%). The majority of the respondents are beneficiaries of health services (54\%). The greatest number of respondents work for less than 10 years $(63.5 \%)$ followed by those who work for $10-15$ years $(16 \%)$ and $(12 \%)$ work for $15-25 y e a r s$. Only $(8.5 \%)$ work for more than 25 years. 


\section{4-3 Descriptive Analysis :(Advantages of privatization hospitals from the sample view)}

Descriptive Statistics

\begin{tabular}{|c|c|c|c|c|c|c|c|c|c|c|c|c|}
\hline \multirow{2}{*}{$\begin{array}{c}\text { Advantages of } \\
\text { privatization hospitals } \\
\text { from the sample } \\
\text { members view: }\end{array}$} & $\mathrm{N}$ & Range & Minimum & Maximum & Sum & \multicolumn{2}{|c|}{ Mean } & \multirow{2}{*}{$\begin{array}{c}\text { Std. } \\
\text { Deviation } \\
\\
\text { Statistic }\end{array}$} & \multicolumn{2}{|c|}{ Skewness } & \multicolumn{2}{|c|}{ Kurtosis } \\
\hline & Statistic & Statistic & Statistic & Statistic & Statistic & Statistic & $\begin{array}{l}\text { Std. } \\
\text { Error }\end{array}$ & & Statistic & $\begin{array}{l}\text { Std. } \\
\text { Error }\end{array}$ & Statistic & $\begin{array}{l}\text { Std. } \\
\text { Error }\end{array}$ \\
\hline $\begin{array}{l}\text { Minimize the financial } \\
\text { burden on the }\end{array}$ & 200 & 4.00 & 1.00 & 5.00 & 712.00 & 3.5600 & .08133 & 1.15022 & -.138 & .172 & -.845 & .342 \\
\hline $\begin{array}{r}\text { Increasing the } \\
\text { government's financial } \\
\text { resources }\end{array}$ & 200 & 4.00 & 1.00 & 5.00 & 715.00 & 3.5750 & .07939 & 1.12280 & -.071 & .172 & -.898 & .342 \\
\hline $\begin{array}{l}\text { Improve the working } \\
\text { environment for health } \\
\text { practitioners }\end{array}$ & 200 & 4.00 & 1.00 & 5.00 & 811.00 & 4.0550 & .08181 & 1.15701 & -.934 & .172 & -.304 & .342 \\
\hline $\begin{array}{r}\text { Satisfaction of } \\
\text { beneficiaries of health } \\
\text { services }\end{array}$ & 200 & 4.00 & 1.00 & 5.00 & 817.00 & 4.0850 & .07918 & 1.11984 & -.928 & .172 & -.189 & .342 \\
\hline $\begin{array}{r}\text { Fast delivery of health } \\
\text { services }\end{array}$ & 200 & 4.00 & 1.00 & 5.00 & 818.00 & 4.0900 & .07932 & 1.12169 & -1.021 & .172 & .075 & .342 \\
\hline $\begin{array}{r}\text { Eliminate the waiting } \\
\text { time of appointments } \\
\text { in hospitals }\end{array}$ & 200 & 4.00 & 1.00 & 5.00 & 822.00 & 4.1100 & .07726 & 1.09264 & -1.271 & .172 & .946 & .342 \\
\hline $\begin{array}{l}\text { Improving the quality } \\
\text { of services provided }\end{array}$ & 200 & 4.00 & 1.00 & 5.00 & 846.00 & 4.2300 & .07254 & 1.02585 & -1.490 & .172 & 1.839 & .342 \\
\hline Valid N (list wise) & 200 & & & & & & & & & & & \\
\hline
\end{tabular}

Table 4-3: The Descriptive Analysis.

As shown in table the descriptive statistics of the gathered data suggests that the respondents have shown agreement in all the responses. The main explains central tendency of data. For improving the quality of services provided and eliminate the waiting time of appointments in hospitals the mean value is 4.23 and 4.11 .

\section{4-3-1 Descriptive Statistics: (Difficulties facing the privatization of the health sector)}

\begin{tabular}{|c|c|c|c|c|c|c|c|c|c|c|c|c|}
\hline \multirow{2}{*}{$\begin{array}{l}\text {-Difficulties facing } \\
\text { the privatization of } \\
\text { the health sector }\end{array}$} & \multirow{2}{*}{$\frac{\mathrm{N}}{\text { Statistic }}$} & \multirow{2}{*}{$\begin{array}{l}\text { Range } \\
\text { Statistic }\end{array}$} & \multirow{2}{*}{$\begin{array}{l}\text { Minimum } \\
\text { Statistic } \\
\end{array}$} & \multirow{2}{*}{$\begin{array}{c}\text { Maximum } \\
\text { Statistic } \\
\end{array}$} & \multirow{2}{*}{$\begin{array}{c}\text { Sum } \\
\text { Statistic }\end{array}$} & \multicolumn{2}{|c|}{ Mean } & \multirow{2}{*}{$\begin{array}{c}\begin{array}{c}\text { Std. } \\
\text { Deviation }\end{array} \\
\text { Statistic } \\
\end{array}$} & \multicolumn{2}{|c|}{ Skewness } & \multicolumn{2}{|c|}{ Kurtosis } \\
\hline & & & & & & Statistic & $\begin{array}{l}\text { Std. } \\
\text { Error }\end{array}$ & & Statistic & $\begin{array}{l}\text { Std. } \\
\text { Error }\end{array}$ & Statistic & $\begin{array}{l}\text { Std. } \\
\text { Error }\end{array}$ \\
\hline $\begin{array}{ll}\text { High costs of } \\
\text { health services }\end{array}$ & 200 & 4.00 & 1.00 & 5.00 & 840.00 & 4.2000 & .06419 & .90781 & -1.506 & .172 & 2.703 & .342 \\
\hline $\begin{array}{l}\text { Investing in the } \\
\text { health sector needs } \\
\text { large capital }\end{array}$ & 200 & 4.00 & 1.00 & 5.00 & 828.00 & 4.1400 & .05211 & .73696 & -1.521 & .172 & 4.721 & .342 \\
\hline $\begin{array}{l}\text { Increase } \\
\text { unemployment } \\
\text { among health } \\
\text { professionals }\end{array}$ & 200 & 4.00 & 1.00 & 5.00 & 763.00 & 3.8150 & .08969 & 1.26839 & -.721 & .172 & -.648 & .342 \\
\hline $\begin{array}{l}\text { Difficulty } \\
\text { rehabilitating } \\
\text { public sector } \\
\text { employees to the } \\
\text { private sector }\end{array}$ & 200 & 4.00 & 1.00 & 5.00 & 691.00 & 3.4550 & .08589 & 1.21464 & -.115 & .172 & -1.134 & .342 \\
\hline $\begin{array}{l}\text { Lack of qualified } \\
\text { administrators for } \\
\text { the management of } \\
\text { health facilities }\end{array}$ & 200 & 4.00 & 1.00 & 5.00 & 705.00 & 3.5250 & .08680 & 1.22756 & -.099 & .172 & -1.422 & .342 \\
\hline $\begin{array}{l}\text { Resistance to } \\
\text { change from some } \\
\text { workers in the } \\
\text { health sector }\end{array}$ & 200 & 4.00 & 1.00 & 5.00 & 846.00 & 4.2300 & .07592 & 1.07372 & -1.258 & .172 & .667 & .342 \\
\hline $\begin{array}{l}\text { Lack of experience } \\
\text { in the private } \\
\text { sector }\end{array}$ & 200 & 4.00 & 1.00 & 5.00 & 736.00 & 3.6800 & .08646 & 1.22273 & -.316 & .172 & -1.268 & .342 \\
\hline $\begin{array}{l}\text { Community } \\
\text { negative attitude } \\
\text { towards society } \\
\text { towards } \\
\text { privatization }\end{array}$ & 200 & 4.00 & 1.00 & 5.00 & 762.00 & 3.8100 & .07648 & 1.08155 & -.650 & .172 & -.388 & .342 \\
\hline $\begin{array}{l}\text { Community } \\
\text { concerns that } \\
\text { health services are } \\
\text { not free. }\end{array}$ & 200 & 4.00 & 1.00 & 5.00 & 804.00 & 4.0200 & .06137 & .86797 & -1.296 & .172 & 2.274 & .342 \\
\hline Valid N (list wise) & 200 & & & & & & & & & & & \\
\hline
\end{tabular}

Table 4-3-1: Descriptive Statistics

As shown in table the descriptive statistics of the gathered data suggests that the respondents have shown 
agreement in all the responses. The main explains central tendency of data. For Resistance to change from some workers in the health sector and eliminate the waiting time of appointments in hospitals the mean valu is 4.23 and 4.20 .

\section{4-3-2: Descriptive Statistics: (The fundamentals of successful privatization)}

\begin{tabular}{|c|c|c|c|c|c|c|c|c|c|c|c|c|c|}
\hline \multirow[b]{2}{*}{$\begin{array}{l}\text { The fundamentals of successful } \\
\text { privatization }\end{array}$} & \multirow{2}{*}{$\frac{\mathrm{N}}{\text { Statistic }}$} & \multirow{2}{*}{\begin{tabular}{|l|} 
Range \\
Statistic \\
\end{tabular}} & \multirow{2}{*}{$\begin{array}{l}\text { Minimum } \\
\text { Statistic } \\
\end{array}$} & \multirow{2}{*}{$\begin{array}{l}\text { Maximum } \\
\text { Statistic } \\
\end{array}$} & \multirow{2}{*}{\begin{tabular}{|c|} 
Sum \\
Statistic \\
\end{tabular}} & \multicolumn{2}{|c|}{ Mean } & \multirow{2}{*}{$\begin{array}{c}\begin{array}{c}\text { Std. } \\
\text { Deviation }\end{array} \\
\text { Statistic }\end{array}$} & \multirow{2}{*}{ Variance } & \multicolumn{2}{|c|}{ Skewness } & \multicolumn{2}{|c|}{ Kurtosis } \\
\hline & & & & & & Statistic & $\begin{array}{l}\text { Std. } \\
\text { Error }\end{array}$ & & & Statistic & $\begin{array}{l}\text { Std. } \\
\text { Error }\end{array}$ & Statistic & $\begin{array}{l}\text { Std. } \\
\text { Error }\end{array}$ \\
\hline $\begin{array}{l}\text { Government support for the } \\
\text { privatization process }\end{array}$ & 200 & 4.00 & 1.00 & 5.00 & 825.00 & 4.1250 & .05800 & .82021 & .673 & -1.229 & .172 & 2.438 & .342 \\
\hline $\begin{array}{l}\text { The government's ability to convince } \\
\text { the community of the usefulness of } \\
\text { privatization }\end{array}$ & 200 & 4.00 & 1.00 & 5.00 & 830.00 & 4.1500 & .07290 & 1.03093 & 1.063 & -1.111 & .172 & .509 & .342 \\
\hline $\begin{array}{l}\text { Ensure a minimum level of health } \\
\text { care for community members }\end{array}$ & 200 & 4.00 & 1.00 & 5.00 & 820.00 & 4.1000 & .06909 & .97713 & .955 & -1.476 & .172 & 2.482 & .342 \\
\hline $\begin{array}{l}\text { Graduation in the process of } \\
\text { privatization }\end{array}$ & 200 & 4.00 & 1.00 & 5.00 & 835.00 & 4.1750 & .06779 & .95863 & .919 & -1.395 & .172 & 2.036 & .342 \\
\hline Apply health insurance & 200 & 4.00 & 1.00 & 5.00 & 764.00 & 3.8200 & .07256 & 1.02609 & 1.053 & -.506 & .172 & -.292 & .342 \\
\hline $\begin{array}{l}\text { Activation of the operating system } \\
\text { for self-vacancy } \\
\text { Setting standards and }\end{array}$ & 200 & 4.00 & 1.00 & 5.00 & 772.00 & 3.8600 & .06801 & .96178 & .925 & -.332 & .172 & -.639 & .342 \\
\hline $\begin{array}{l}\text { specifications for expected health } \\
\text { services } \\
\text { Creating regulatory levels for the } \\
\text { privatization process }\end{array}$ & 200 & 4.00 & 1.00 & 5.00 & 862.00 & 4.3100 & .06276 & .88760 & .788 & -1.610 & .172 & 3.152 & .342 \\
\hline Valid N (list wise) & 200 & & & & & & & & & & & & \\
\hline
\end{tabular}

Table 4-3-2: Descriptive Statistics.

As shown in table the descriptive statistics of the gathered data suggests that the respondents have shown agreement in all the responses. The main explains central tendency of data. For setting standards and specifications of expected health services the mean value is 4.35 and 4.31 .

\section{4-4 Correlations Analysis:}

\section{Correlations}

\begin{tabular}{|c|c|c|c|c|c|}
\hline & $\begin{array}{l}\text { Impact of } \\
\text { privatization } \\
\text { in health } \\
\text { sector }\end{array}$ & $\begin{array}{c}\text { Spending } \\
\text { Reduce }\end{array}$ & $\begin{array}{c}\text { Improve } \\
\text { management }\end{array}$ & $\begin{array}{l}\text { Satisfaction } \\
\text { of } \\
\text { beneficiaries }\end{array}$ & $\begin{array}{l}\text { Improving work } \\
\text { environment of } \\
\text { health } \\
\text { practitioners }\end{array}$ \\
\hline \begin{tabular}{|lcl}
$\begin{array}{l}\text { Impact } \\
\text { privatization }\end{array}$ & of & Pearson \\
health sector & Correlation \\
& Sig. (2-tailed) \\
& $\mathrm{N}$ \\
\end{tabular} & $\begin{array}{r}1 \\
200 \\
\end{array}$ & $\begin{array}{l}.697^{* *} \\
.000 \\
200 \\
\end{array}$ & $\begin{array}{l}.748^{* *} \\
.000 \\
200 \\
\end{array}$ & $\begin{array}{l}.858^{* *} \\
.000 \\
200 \\
\end{array}$ & $\begin{array}{l}.892^{* *} \\
.000 \\
200 \\
\end{array}$ \\
\hline $\begin{array}{l}\text { Pearson } \\
\text { Correlation } \\
\text { Sig. (2-tailed) } \\
\mathrm{N} \\
\end{array}$ & $\begin{array}{l}.697^{* *} \\
.000 \\
200 \\
\end{array}$ & $\begin{array}{r}1 \\
200 \\
\end{array}$ & $\begin{array}{l}.415^{* *} \\
.000 \\
200 \\
\end{array}$ & $\begin{array}{l}.404^{* *} \\
.000 \\
200 \\
\end{array}$ & $\begin{array}{l}.533^{* *} \\
.000 \\
200\end{array}$ \\
\hline \begin{tabular}{|ll} 
Improve & Pearson \\
management. & Correlation \\
& Sig. (2-tailed) \\
& $\mathrm{N}$ \\
\end{tabular} & $\begin{array}{l}.748^{* *} \\
.000 \\
200 \\
\end{array}$ & $\begin{array}{l}.415^{* *} \\
.000 \\
200 \\
\end{array}$ & 200 & $\begin{array}{l}.530^{* *} \\
.000 \\
200 \\
\end{array}$ & $\begin{array}{l}.714^{* *} \\
.000 \\
200 \\
\end{array}$ \\
\hline $\begin{array}{lll}\begin{array}{l}\text { Satisfaction } \\
\text { beneficiaries }\end{array} & \text { Pearson } \\
& \text { Correlation } \\
& \text { Sig. (2-tailed) } \\
& \mathrm{N} \\
\end{array}$ & $\begin{array}{l}.858^{* *} \\
.000 \\
200 \\
\end{array}$ & $\begin{array}{l}.404^{* *} \\
.000 \\
200 \\
\end{array}$ & $\begin{array}{c}.530^{* *} \\
.000 \\
200 \\
\end{array}$ & $\begin{array}{c}1 \\
200 \\
\end{array}$ & $\begin{array}{c}.691^{* *} \\
.000 \\
200 \\
\end{array}$ \\
\hline $\begin{array}{lll}\text { Improving work } & \text { Pearson } \\
\text { environment of } & \text { Correlation } \\
\text { health } & \text { Sig. (2-tailed) } \\
\text { practitioners. } & \mathrm{N} \\
\end{array}$ & $\begin{array}{c}.892^{* *} \\
.000 \\
200\end{array}$ & $\begin{array}{c}.533^{* *} \\
.000 \\
200\end{array}$ & $\begin{array}{c}.714^{* *} \\
.000 \\
200\end{array}$ & $\begin{array}{c}.691^{* *} \\
.000 \\
200\end{array}$ & 200 \\
\hline
\end{tabular}

**. Correlation is significant at the 0.01 level (2-tailed).

Table 4-4: Correlation Analysis

The correlation between the dependent variables and independent variable is shown in the table above .The independent variable in this study is impact of privatization in health sector while the dependent variables are 
(Spending Reduce, Improve management, Satisfaction of beneficiaries. Improving work environment of health practitioners). The Pearson correlation between the impact and dependent variables (Spending Reduce, Improve management, Satisfaction of beneficiaries. Improving work environment of health practitioners) is very strong and positive that's reflected by the high $\mathrm{R}$ values of $0.697,0.748,0.858$ and 0.892 . Thus an increase of the level spending reduce are reflected to increase of impact, and a decrease of levels spending reduce, improve management, satisfaction of beneficiaries. Improving work environment of health practitioners) are associate with a decrease in impact of privatization in health sector. The Sig. (2-Tailed) value between the involved (Spending Reduce, Improve management, Satisfaction of beneficiaries. Improving work environment of health practitioners) equal to 0.000 that is less than 0.05 which mean there is a significant correlation between dependent variables and independent variable. Therefore, based on the results of the analysis, the H01, H02, H03, and H04 are rejected and HA1, HA2, HA3, and HA4 are accepted.

\section{4-5 Factor Analysis:}

\section{KMO and Bartlett's Test}

Kaiser-Meyer-Olkin Measure of Sampling Adequacy.

Bartlett's Test of Sphericity Approx. Chi-Square

755

336.337

df

.000

Table 4-5: KMO and Bartlett's Test

Table 4.5 clarifies that the value of KMO test which equal 0.755 , thus the sampling adequacy is acceptable for the factor analysis, According to Bartlett's test of Sphericity, which is below 0.05 and equals 0.000 , the data have been gathered is suitable and the suitability and validity are high.

Anti-image Matrices

\begin{tabular}{|c|c|c|c|c|c|}
\hline & & $\begin{array}{l}\text { Spending } \\
\text { Reduce }\end{array}$ & Improve management & $\begin{array}{c}\text { Satisfaction of } \\
\text { beneficiaries }\end{array}$ & $\begin{array}{c}\text { Improving work } \\
\text { environment of } \\
\text { health }\end{array}$ \\
\hline \multirow{4}{*}{$\begin{array}{l}\text { Anti-image } \\
\text { Covariance }\end{array}$} & Spending Reduce & .712 & -.032 & -.033 & -.143 \\
\hline & Improve management & -.032 & .486 & -.034 & -.208 \\
\hline & $\begin{array}{l}\text { Satisfaction of } \\
\text { beneficiaries }\end{array}$ & -.033 & -.034 & .518 & -.199 \\
\hline & $\begin{array}{l}\text { Improving work } \\
\text { environment of health }\end{array}$ & -.143 & -.208 & -.199 & .322 \\
\hline \multirow{4}{*}{$\begin{array}{l}\text { Anti-image } \\
\text { Correlation }\end{array}$} & Spending Reduce & $.868^{a}$ & -.054 & -.054 & -.298 \\
\hline & Improve management & -.054 & $.773^{\mathrm{a}}$ & -.068 & -.525 \\
\hline & $\begin{array}{l}\text { Satisfaction of } \\
\text { beneficiaries }\end{array}$ & -.054 & -.068 & $.791^{\mathrm{a}}$ & -.486 \\
\hline & $\begin{array}{l}\text { Improving work } \\
\text { environment of health }\end{array}$ & -.298 & -.525 & -.486 & $.679^{a}$ \\
\hline
\end{tabular}

a. Measures of Sampling Adequacy(MSA)

Table 4-5-1: Anti- image Matrices

The Measures of Sampling Adequacy (MSA) must be above 0.5. Table 4-5-1 points that the value of each individual variable is well above 0.5 , so the MSA overall and for each variable is sufficiently large. The MSA for Spending Reduce value is equal to 0.868 while Improve management is 0.907 , The Satisfaction of beneficiaries MSA value is equal to 0.791 , and Improving work environment of health is 0.679 .

\section{Communalities}

\begin{tabular}{|l|r|r|}
\hline & Initial & Extraction \\
Spending Reduce & 1.000 & .485 \\
Improve management & 1.000 & .681 \\
Satisfaction of beneficiaries & 1.000 & .660 \\
Improving work environment of health & 1.000 & .837 \\
\hline
\end{tabular}

Extraction Method: Principal Component Analysis.

Table 4-5-2: Communalities 
Communalities represent the extent of the variance. As the table indicates, the communalities are high due to their values which are above 0.5 on all variables. $48.5 \%$ of the variance is accounted for spending reduce, $68.1 \%$ of the variance is accounted for improve management, $66.0 \%$ satisfaction of beneficiaries, $83.7 \%$ improving work environment of health.

\section{Component Matrix ${ }^{\mathrm{a}}$}

\begin{tabular}{|l|c|}
\hline & Component \\
\cline { 2 - 2 } & \multicolumn{1}{|c|}{4} \\
\hline Spending Reduce & .696 \\
Improve management & .825 \\
Satisfaction of beneficiaries & .812 \\
\hline Improving work environment of health & .915 \\
\hline
\end{tabular}

Extraction Method: Principal Component Analysis. a. 4 components extracted.

Table 4-5-3: Component Matrix (The table presents the loading of four variables on the four factors extracted).

\section{4-6 Reliability}

\section{Case Processing Summary}

\begin{tabular}{|ll|r|r|}
\hline & & $\mathrm{N}$ & \multicolumn{1}{|c|}{$\%$} \\
\hline Cases & Valid & 200 & 100.0 \\
& Excluded $^{\mathrm{a}}$ & 0 & .0 \\
& Total & 200 & 100.0 \\
\hline
\end{tabular}

a. Listwise deletion based on all variables in the procedure

Table 4-6: Case Processing Summary

Reliability Statistics

\begin{tabular}{|c|c|c|}
\hline Cronbach's Alpha & $\begin{array}{c}\text { Cronbach's Alpha Based on } \\
\text { Standardized Items }\end{array}$ & N of Items \\
\hline .750 & .754 & 10 \\
\hline
\end{tabular}

Table 4-6-1: Reliability Statistics

The table shows that Cronbach's Alpha coefficient is a above 0.750, thus the

Reliability is of the scale is good and acceptable.

\begin{tabular}{|l|l|l|l|}
\hline \multicolumn{3}{|c|}{ Item Statistics } & Std. Deviation \\
\hline q 1 & Mean & 1.15022 & 200 \\
q 2 & 1.12280 & 200 \\
q 3 & 3.5600 & 1.15701 & 200 \\
q4 & 3.5750 & 1.11984 & 200 \\
q5 & 4.0550 & 1.12169 & 200 \\
q6 & 4.0850 & 1.09264 & 200 \\
q7 & 4.0900 & 1.02585 & 200 \\
q8 & 4.1100 & .90781 & 200 \\
q9 & 4.2300 & .73696 & 200 \\
q10 & 4.2000 & 1.26839 & 200 \\
\hline
\end{tabular}

Table 4-6-2: Item Statistics

\section{4-7 Variance Explained}

Total Variance Explained

\begin{tabular}{|l|r|r|r|r|r|r|}
\hline \multirow{2}{*}{ Component } & \multicolumn{3}{|c|}{ Initial Eigenvalues } & \multicolumn{2}{c|}{ Extraction Sums of Squared Loadings } \\
\cline { 2 - 7 } & Total & $\begin{array}{c}\text { \% of } \\
\text { Variance }\end{array}$ & Cumulative \% & Total & \% of \\
Variance & Cumulative \% \\
\hline Spending Reduce & 2.663 & 66.580 & 66.580 & 2.663 & 66.580 & 66.580 \\
Improve management & .641 & 16.013 & 82.593 & & & \\
Satisfaction of beneficiaries & .471 & 11.770 & 94.362 & & & \\
Improving work environment & .226 & 5.638 & 100.000 & & & \\
of health & & & & & \\
\hline
\end{tabular}

Table 4-7:Total Variance Explained (Extraction Method: Principal Component Analysis.) 


\section{4-8 Simple Linear Regression}

\begin{tabular}{|c|c|c|c|c|}
\hline \multicolumn{5}{|c|}{ Model Summary } \\
\hline Model & $\mathrm{R}$ & R Square & Adjusted R Square & Std. Error of the Estimate \\
\hline 1 & $.633^{\mathrm{a}}$ & .401 & 398 & .37927 \\
\hline
\end{tabular}

a. Predictors: (Constant), Impact privatization

Table 4-8: Model Summary

This table provides the $R$ and $R^{2}$ values. The $R$ value represents the simple correlation and is 0.633 , which indicates a high degree of correlation. The R2 value indicates how much of the total variation in the dependent variable Spending Reduce, can be explained by the independent variable, Impact privatization. In this case, $40.1 \%$ can be explained, which is medium.

The next table is the ANOVA table, which reports how well the regression equation fits the data (i.e., predicts the dependent variable) and is shown below:

\begin{tabular}{|cl|r|r|r|r|r|}
\hline Model & \multicolumn{1}{|c|}{ ANOVA $^{\mathbf{a}}$} & \multicolumn{1}{c|}{ S } & Sig. \\
\hline & Sum of Squares & Df & Mean Square & \multicolumn{1}{c|}{ F } & $.000^{\mathrm{b}}$ \\
& Regression & 19.084 & 1 & 19.084 & 132.664 & \\
& Residual & 28.482 & 198 & .144 & & \\
& Total & 47.566 & 199 & & & \\
\hline
\end{tabular}

a. Dependent Variable: Spending reduce

b. Predictors: (Constant), Impact privatization

Table 4-8-1: ANOVA $^{\mathrm{a}}$

This table indicates that the regression model predicts the dependent variable significantly well. This indicates the statistical significance of the regression model that was run. Here, $\mathrm{p}<0.0005$, which is less than 0.05 , and indicates that, overall, the regression model statistically significantly predicts the outcome variable.

The Coefficients table provides us with the necessary information to predict spending reduce from impact privatization, Furthermore, we can use the values in the "B" column under the "Unstandardized Coefficients" column, as shown below:

\begin{tabular}{|c|c|c|c|c|c|c|}
\hline \multirow[b]{3}{*}{ Model } & & \multicolumn{3}{|c|}{ Coefficients $^{\mathbf{a}}$} & \multirow[b]{3}{*}{$\mathrm{T}$} & \multirow[b]{3}{*}{ Sig. } \\
\hline & & \multicolumn{2}{|c|}{ Unstandardized Coefficients } & $\begin{array}{l}\text { Standardized } \\
\text { Coefficients }\end{array}$ & & \\
\hline & & $\mathrm{B}$ & Std. Error & Beta & & \\
\hline 1 & $\begin{array}{l}\text { (Constant) } \\
\text { Impact privatization }\end{array}$ & $\begin{array}{l}1.177 \\
.528\end{array}$ & $\begin{array}{l}.190 \\
.046\end{array}$ & .633 & $\begin{array}{l}6.185 \\
11.518\end{array}$ & $\begin{array}{l}.000 \\
.000\end{array}$ \\
\hline
\end{tabular}

a. Dependent Variable: Spending Reduce

Table 4-8-2: Coefficients ${ }^{\mathrm{a}}$

Present the regression equation as: Spending Reduce $=1.177+0.528$ (Impact privatization). Thus the Impact of privatization affect is positive on spending reduce statistically significantly

Model Summary

\begin{tabular}{|l|r|r|r|r|}
\hline Model & R & R Square & \multicolumn{1}{|c|}{ Adjusted R Square } & \multicolumn{1}{|c|}{ Std. Error of the Estimate } \\
\hline 1 & $.795^{\mathrm{a}}$ & .632 & .630 & .33895 \\
\hline
\end{tabular}

a. Predictors: (Constant), Impact privatization

Table 4-8-3: Model Summary

This table provides the $R$ and $R^{2}$ values. The $R$ value represents the simple correlation and is 0.795 , which indicates a high degree of correlation. The R2 value indicates how much of the total variation in the dependent variable improve management, can be explained by the independent variable, impact privatization. In this case, $63.2 \%$ can be explained, which is large.

The next table is the ANOVA table, which reports how well the regression equation fits the data (i.e., predicts the dependent variable) and is shown below:

\begin{tabular}{|ll|l|l|l|l|l|}
\hline Model & & ANOVA & \\
\hline & Sum of Squares & df & Mean Square & F & Sig. \\
& Regression & 39.100 & 1 & 39.100 & 340.343 & $.000^{\mathrm{b}}$ \\
& Residual & 22.747 & 198 & .115 & & \\
& Total & 61.848 & 199 & & & \\
\hline
\end{tabular}

a. Dependent Variable: Improve management

b. Predictors: (Constant), Impact privatization

Table 4-8-4: ANOVA $^{\mathrm{a}}$ 
This table indicates that the regression model predicts the dependent variable significantly well. This indicates the statistical significance of the regression model that was run. Here, $\mathrm{p}<0.0005$, which is less than 0.05 , and indicates that, overall, the regression model statistically significantly predicts the outcome variable.

The Coefficients table provides us with the necessary information to predict: improve management from impact privatization. Furthermore, we can use the values in the "B" column under the "Unstandardized Coefficients" column, as shown below:

\section{Coefficients}

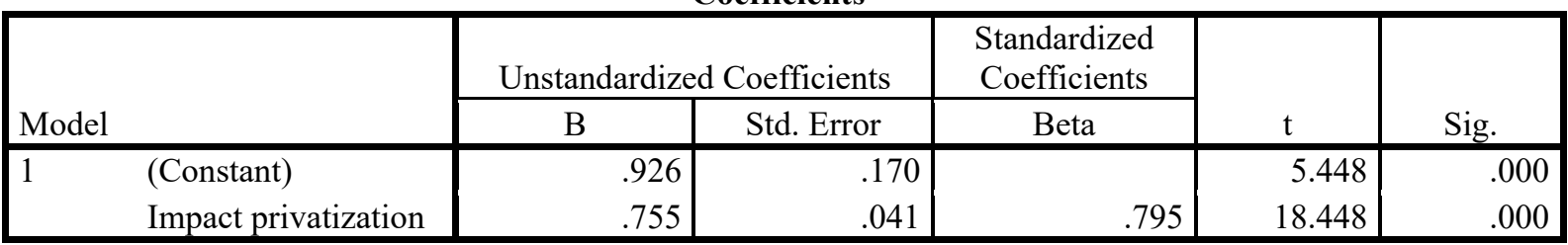

a. Dependent Variable: Improve management

Table 4-8-5: Coefficients ${ }^{\mathrm{a}}$

Present the regression equation as: Improve management $=0.926+0.755$ (Impact privatization). Thus the Impact of privatization affect is positive on improve management statistically significantly.

\section{Model Summary}

\begin{tabular}{|l|r|r|r|r|}
\hline Model & R & \multicolumn{1}{|c|}{ R Square } & Adjusted R Square & Std. Error of the Estimate \\
\hline 1 & $.571^{\mathrm{a}}$ & .326 & .323 & .53324 \\
\hline
\end{tabular}

a. Predictors: (Constant), Impact privatization

Table 4-8-6: Model Summary

This table provides the $R$ and $R^{2}$ values. The $R$ value represents the simple correlation and is 0.571 , which indicates a high degree of correlation. The R2 indicates how much of the total variation in the dependent variable improve management, can be explained by the independent variable, impact privatization. In this case, $32.6 \%$ can be explained, which is medium.

The next table is the ANOVA table, which reports how well the regression equation fits the data (i.e., predicts the dependent variable) and is shown below:

\begin{tabular}{|ll|l|l|l|l|l|}
\hline Model & & ANOVA & \\
\hline 1 & Sum of Squares & df & Mean Square & F & Sig. \\
& Regression & 27.249 & 1 & 27.249 & 95.829 & $.000^{\mathrm{b}}$ \\
& Residual & 56.301 & 198 & .284 & & \\
& Total & 83.549 & 199 & & & \\
\hline
\end{tabular}

a. Dependent Variable: Satisfaction of beneficiaries

b. Predictors: (Constant), Impact privatization

\section{Table 4-8-7: ANOVA $^{\mathrm{a}}$}

This table indicates that the regression model predicts the dependent variable significantly well. This indicates the statistical significance of the regression model that was run. Here, $p<0.0005$, which is less than 0.05 , and indicates that, overall, the regression model statistically significantly predicts the outcome variable.

The Coefficients table provides us with the necessary information to predict: Satisfaction of beneficiaries from Impact privatization. Furthermore, we can use the values in the "B" column under the "Unstandardized Coefficients" column, as shown below:

\section{Coefficients}

\begin{tabular}{|c|c|c|c|c|c|c|}
\hline \multirow[b]{2}{*}{ Model } & & \multicolumn{2}{|c|}{ Unstandardized Coefficients } & \multirow{2}{*}{$\frac{\text { Standardized Coefficients }}{\text { Beta }}$} & \multirow[b]{2}{*}{$\mathrm{T}$} & \multirow[b]{2}{*}{ Sig. } \\
\hline & & $\mathrm{B}$ & Std. Error & & & \\
\hline & (Constant) & 1.447 & .267 & & 5.410 & .000 \\
\hline & Impact privatization & .630 & .064 & .571 & 9.789 & .000 \\
\hline
\end{tabular}

a. Dependent Variable: Satisfaction of beneficiaries

Table 4-8-8: Coefficients ${ }^{\mathrm{a}}$

Present the regression equation as: Satisfaction of beneficiaries $=1.447+0.630$ (Impact privatization). Thus the Impact of privatization affect is positive on of Satisfaction beneficiaries statistically significantly.

\section{Model Summary}

\begin{tabular}{|l|r|r|r|r|}
\hline Model & \multicolumn{1}{|c|}{$\mathrm{R}$} & \multicolumn{1}{|c|}{ R Square } & \multicolumn{1}{c|}{ Adjusted R Square } & Std. Error of the Estimate \\
\hline 1 & $.835^{\mathrm{a}}$ & .697 & .695 & .27574 \\
\hline
\end{tabular}

a. Predictors: (Constant), Impact privatization

Table 4-8-9: Model Summary 
This table provides the $R$ and $R^{2}$ values. The $R$ value represents the simple correlation and is 0.835 , which indicates a high degree of correlation. The $\mathrm{R} 2$ indicates how much of the total variation in the dependent variable improve management, can be explained by the independent variable, impact privatization. In this case, $69.7 \%$ can be explained, which is large.

The next table is the ANOVA table, which reports how well the regression equation fits the data (i.e., predicts the dependent variable) and is shown below:

\begin{tabular}{|ll|l|l|l|l|l|}
\hline Model & & Sum of Squares & df & Mean Square & F & Sig. \\
\hline 1 & Regression & 34.633 & 1 & 34.633 & 455.507 & $.000^{\mathrm{b}}$ \\
& Residual & 15.054 & 198 & .076 & & \\
& Total & 49.688 & 199 & & & \\
\hline
\end{tabular}

a. Dependent Variable: Improving work environment of health practitioners

b. Predictors: (Constant), Impact privatization

Table 4-8-10: ANOVA $^{\mathrm{a}}$

This table indicates that the regression model predicts the dependent variable significantly well. This indicates the statistical significance of the regression model that was run. Here, $\mathrm{p}<0.0005$, which is less than 0.05 , and indicates that, overall, the regression model statistically significantly predicts the outcome variable.

The Coefficients table provides us with the necessary information to predict: Improving work environment of health practitioners from impact privatization. Furthermore, we can use the values in the "B" column under the "Unstandardized Coefficients" column, as shown below:

Coefficients $^{\mathrm{a}}$

\begin{tabular}{|c|c|c|c|c|c|c|}
\hline \multirow{2}{*}{\multicolumn{2}{|c|}{ Model }} & \multicolumn{2}{|c|}{ Unstandardized Coefficients } & $\begin{array}{l}\text { Standardized } \\
\text { Coefficients }\end{array}$ & \multirow[b]{2}{*}{$\mathrm{t}$} & \multirow[b]{2}{*}{ Sig. } \\
\hline & & $\mathrm{B}$ & Std. Error & Beta & & \\
\hline & (Constant) & .730 & .138 & & 5.276 & .000 \\
\hline & Impact privatization & .711 & .033 & .835 & 21.343 & .000 \\
\hline
\end{tabular}

a. Dependent Variable: Improving work environment of health practitioners

Table 4-8-11: Coefficients ${ }^{\mathrm{a}}$

Present the regression equation as: Improving work environment of health practitioners $=0.730+$ 0.711(Impact privatization). Thus the impact of privatization affect is positive on of satisfaction beneficiaries statistically significantly.

\section{5-1 Summary:}

The process of economic transformation is one of the most difficult, and sophisticate processes undertaken by countries. The multiplicity of modes of transformation opens up a wider scope to try to choose the best way of maximum benefit for the country and society. Saudi Arabia has adopted the privatization method in the 2030 economic transformation program. This is one of the most important challenges facing the country in the coming years, with planning, implementation, and the establishment of control devices in the process. Privatization is one of the most common forms of economic transformation adopted by both developed countries and developing countries. As some studies show their positive impact on the economies of the countries (Al-Ali, 2012). Privatization is a way of thinking and a utilitarian tool based on the vision of a new system for the division of labor and functions of the national economy between the government and the private sector. The division of labor in a single direction is the possibility of the government and the public sector abandoning some jobs and activities of the private sector. Broader privatization refers to the introduction of market forces, supply and demand mechanisms and competition to the country's economy. The decision to privatize carries a high degree of risk to governments, which always have to reduce the degree of political opposition and reach acceptable rates, along with taking appropriate measures that can result in a successful privatization program, to generate some kind of popular approval and support. It is known that the desired change will not always succeed unless it is express by well convince of those who affected by it. If, however, they are not convinced of them, the resistance will rise, especially since the implementation of any new development policy requires efforts and sacrifices. The Ministry of Health is the main provider of health services in Saudi Arabia. The health sector is considered one of the most important sector and carries great sensitivity due to its nature, its services and the nature of the people being dealt with. Saudi Arabia has decided to include the Ministry of Health in the process of privatization. This study indicates the impact of the process of privatization on the Saudi health sector and its impact on several factors, including rationalization of government spending on the health sector, improving management, satisfaction of beneficiaries of health services, and improving the working environment of health practitioners. The results show that some sample of society see the process as vague and not understood in general, but see the beneficiaries of 
services within the scope of their understanding of privatization that if this process well may contribute positively to eliminate the spacing of medical appointments and waiting time and also improve the services while the results showed that the proportion not insignificant workers may tend to resist change. In the view of the sample society, its implementation should be within a clear and unambiguous plan to make it successful in rationalizing government spending, starting health insurance procedures and activating self-employment programs before the privatization is fully privatized so that the government reaches the goal of reducing spending and obtaining economic savings for the country.

\section{References}

Akinci, F., 2002. Privatization in Health Care: Theoretical Considerations and Real Outcomes. Journal of Economics and Economic Education Research, 3(2), 62-86.

Alaamri, S. B. A., and Alghanim, A. B., 2011. Attitudes of Officials in the Saudi Health Sector towards the privatization of Government Hospitals: An Empirical Study on the Ministry of Health. Administrative Sciences, 23(2), 223-252.

Al-Ali, L. H., 2002. Factors Affecting Attitudes toward Privatization of the Public Health Sector in Jorden. Master Thesis, the University of Jordan, School of Graduate Studies.

Alateeq, F. B. A., 2002. Saudi Arabia's experience in running government hospitals: switching from a corporateoperating to a self-operating system. ARADO - Arab Administrative Development Organization. Cairo.

Albreht, T., 2009. Privatization processes in health care in Europe - a move in the right direction, a 'trendy' option, or a step back?. European Journal of Public Health, (19) 5, 448-450.

Al-Buridi, A.M., 2008. Developing management of privatization: an empirical study on the barriers hindering implementation of the program in Saudi Arabia and a proposed efficient model (Doctoral dissertation, Edinburgh Napier University).

Al-Ghamdi, M., Al-Ghamdi, S., and Al-Raddadi, M., 2004. An empirical study of the attitudes of Saudi Arabian Airlines employees toward privatization at: $<$ http://faculty.kfupm.edu.sa/COE/sadiq/proceedings/SCAC2004/21.ASC046.EN.AlGhamdi.An\%20Emp iric al\%20Study\%20of\%20the\%20Attitude\%20_1_.pdf.

Alkhamis, A.A., 2017. Critical analysis and review of the literature on healthcare privatization and its association with access to medical care in Saudi Arabia. Journal of infection and public health, 10(3), 258-268.

Al-Modaf, O. A., 2003. Attitudes toward the effects of privatization on the employment system: A study of undergraduate college students in Saudi Arabia (Doctoral dissertation, Virginia Tech).

Al-Mutairi, A., Naser, K., and Fayez, F., 2014. Employees and managers attitude towards privatization programs: evidence from an emerging economy. International Journal of Economics and Finance, 6(12), 95-96.

Alroqy, F.A., 2010. The impact of privatization on management accounting control systems: a case study of two Saudi Arabian privatized companies. (Doctoral dissertation, Newcastle University).

Alsibai, Z., 2001. Health economics in the Kingdom of Saudi Arabia: (Published article), Jeddah, 39(7).

Braithwaite, J, Travaglia, JF, and Corbett, A., 2011. Can questions of the privatization and corporatization, and the autonomy and accountability of public hospitals, ever be resolved? Health Care Anal; 19 (2), 53-133.

Boardman, C.E., and Vining A., 2012. A Review and Assessment of Privatization in Canada. SPP Research Paper No. $12-5$.

Çınar, F. and Eren, E., 2013. Impacts of privatization of management of health organizations on public health: Turkish Health Sector Evaluation. Procedia - Social and Behavioral Sciences, 99(14), 726-732.

Claessens, S., and Djankov, S., 2002. Privatization benefits in Eastern Europe. Journal of Public Economics, 83(3), 307-324.

Davari, M., Haycox, A., and Walley, T., 2012. Health care financing in Iran; is privatization a good solution?. Iranian journal of public health, 41(7), 14-23.

Dilger, R.J., Moffett, R.R., and Struyk, L., 1997. Privatization of municipal services in America's largest cities. Public Administration Review, 57(1), 21-26.

Dzakpasu, C., 2000, Privatization and management development in Africa, Interdepartmental Action programmed on Privatization, Restructuring and Economic Democracy Working Paper - IPPRED- 2000.

Esfandiari, L., Khalilifar, S., and Esfandiari, S., 2011. The impact of privatization on pattern of human resource performances in Iranian public Enterprises. In Proceedings of International Conference on Software and Computer Applications (ICSCA 2011).

Falkenberg, H., 2010. How privatization and corporatization affect healthcare employees' work climate, work attitudes and ill-health: Implications of social status (Doctoral dissertation, Department of Psychology, Stockholm University).

Guimarães, C.M. and de Carvalho, J.C., 2011, January. Outsourcing in the healthcare sector-a state-of-the-art review. In Supply Chain Forum: An International Journal, 12(2), 140-148.

Hadizadeh, A., 2010. Privatization of Industrial In Iran: A Case Study of Tehran City, PhD Thesis, chapter 
(Privatization Conceptual Understanding, Theoretical Foundation \& Empirical Perspective), 31-37.

Hanke, H., 1987. Privatization and Development, International Center for Economic Growth."The Necessity of Property Rights", Francisco, ICS Press, Chapter 6.

Hebrang, A., Henigsberg, N., Erdeljic, V., Foro, S., Vidjak, V. ,Grga, A., and Macek, T., 2003. Privatization in the health care system of Croatia: effects on general practice accessibility. Health Policy and Planning; 18(4), $421-428$.

Jaffery, A., 2000, Economic Freedom and Privatization-From Egypt and Mesopotamia to Eastern Europe, Economic Freedom and Privatization, 28(4), 365-381.

Jresat, S. S., 2012. The impact of privatization on the performance of human resources in the Jordanian Cement Company in terms of employees' performance and the increase in the salaries and incentives. Interdisciplinary Journal of Contemporary Research in Business, 4(7), 353-366.

Kallianiotis, I., 2018. Privatization in Greece and Its Negative Effects on the Nation's Social Welfare (Expropriation of the National Wealth). Journal of Business and Economic Studies, 19(1), 37-65.

Kettl, D. F., 1993. Sharing power: public governance and private markets. Washington, D.C., The Brookings Institution.

Lewis, R., Smith, J., and Harrison, A., 2009. From quasimarket to market in the National Health Service in England: what does this mean for the purchasing of health services? J Health Services Res Policy; 14(1), 44-51.

Norment, R ., 2010. Fundamentals of public partnerships (PPPs). Arlington, VA: The National Council for Public - Private Part - nerships.

Omran, M., 2004. 'The Performance of State-Owned Enterprises and Newly Privatized Firms: Does Privatization Really Matter?' World Development, 32(6), 1019-1041.

Onour, I., 2012. Implementing Privatization Strategy of Saudi Arabia: Issues and Challenges. SSRN Electronic Journal, DOI: 10.2139/ssrn.2189804.

Perrot, J., 2012. Strategic Contracting for health systems and services, Transaction Publishers. First ed. Ch 2, $125-$ 128

Ram, P., and Prabhakar, G., 2011. Privatizing monopolies in the Telecom Sector-Lessons from the employee job satisfaction perspective. International Journal of Humanities and Social Science, 1(6), 79-88.

Ram, P., 2012. Post privatization job satisfaction among employees. International Journal of Academic Research in Business and Social Sciences, 2(1), 118-119.

Saaeti, A., 2012. Privatization of public hospitals in Saudi Arabia: Journal of Business Research (Faculty of Commerce - Zagazig University) - Egypt, 2(34).

Saudi Arabia, Ministry of Health., 2018. Available at: www.moh.gov.sa.

Sclar, ED., 2000. You Don’t Always Get What You Pay For. Ithaca, NY: Cornell University Press.

Sheshinski, E. and López-Calva, Luis F., 2003. Privatization and Its Benefits: Theory and Evidence. CESifo Economic Studies, 49(3), 429-459.

Suleiman, EN., and Waterbury, J., 1990. Introduction: analyzing privatization in industrial and developing countries. The Political Economy of Public Sector Reform and Privatization. Boulder, Colo: West-view Press: 4.

Swai, L., 2014. The Impact of Privatization on Employees' Quality of Work Life: the Case of Tanzania Breweries Limited and Tanzania Electricity Supply Company Limited (Doctoral dissertation, The Open University of Tanzania)

Tiemann, O., and Schreyögg, J., 2012. Changes in hospital efficiency after privatization. Health Care Management Science, 15(4), 310-326.

Villa, S., and Kane, N., 2013. Assessing the impact of privatizing public hospitals in three American states: implications for universal health coverage. Value in Health, 16(1),24-33.

Waitzkin, H., Jasso-Aguilar, R., and Iriart, C., 2007. Privatization of health services in less developed countries: an empirical response to the proposals of the World Bank and Wharton School. International Journal of Health Services, 37(2),205-227.

Yip, W., and Hsiao, W., 2014. Harnessing the privatization of China's fragmented health-care delivery. The Lancet, 384(9945), 805-818.

Yonnedi, E., 2009. Does privatization affect organizational change: A case of Indonesia. In 10th Public Management Research Conference, Ohio State University, 1-3. 